\title{
The effect of ovine peripheral blood mononuclear cells on Haemonchus contortus larval death in vitro
}

\author{
Elizabeth Anne Shepherd
}

Follow this and additional works at: https://researchrepository.wvu.edu/etd

\section{Recommended Citation}

Shepherd, Elizabeth Anne, "The effect of ovine peripheral blood mononuclear cells on Haemonchus contortus larval death in vitro" (2016). Graduate Theses, Dissertations, and Problem Reports. 6628. https://researchrepository.wvu.edu/etd/6628

This Thesis is protected by copyright and/or related rights. It has been brought to you by the The Research Repository @ WVU with permission from the rights-holder(s). You are free to use this Thesis in any way that is permitted by the copyright and related rights legislation that applies to your use. For other uses you must obtain permission from the rights-holder(s) directly, unless additional rights are indicated by a Creative Commons license in the record and/ or on the work itself. This Thesis has been accepted for inclusion in WVU Graduate Theses, Dissertations, and Problem Reports collection by an authorized administrator of The Research Repository @ WVU. For more information, please contact researchrepository@mail.wvu.edu. 
The effect of ovine peripheral blood mononuclear cells on Haemonchus contortus larval death in vitro

\author{
Elizabeth Anne Shepherd
}

Thesis submitted to the Davis College of Agriculture, Natural Resources and Design at West Virginia University in partial fulfillment of the requirements for the degree of

Master of Science in Animal Physiology

\author{
Scott A. Bowdridge, Ph.D., Chair \\ Robert A. Dailey, Ph.D. \\ Robert L. Taylor, Ph.D.
}

Division of Animal and Nutritional Sciences

Morgantown, West Virginia

2016

Keywords: ATP, Cellular Immunity, Haemonchus contortus, Larval Motility, St. Croix

Copyright 2016 Elizabeth Shepherd 


\section{ABSTRACT \\ The effect of ovine peripheral blood mononuclear cells on Haemonchus contortus larval death in vitro Elizabeth Anne Shepherd}

Gastrointestinal nematode parasitism is the greatest problem facing small ruminant livestock, largely due to development of anthelmintic resistance. Of particular concern is Haemonchus contortus, a hematophagous trichostrongylid that can lead to death in lambs or immunocompromised sheep. Some breeds of sheep are resistant to Haemonchosis, e.g. St. Croix (STC) hair sheep. St. Croix sheep have well-documented resistance and have been shown to develop a robust immune response, generating a rapid cellular response to larval stages that does not occur in susceptible sheep. Studies evaluating effects of mononuclear cells, including monocytes and lymphocytes, indicate that these cells dramatically reduce motility of $H$. contortus larval motility in vitro. Furthermore, breed affected larval motility. However, lack of motility may also have been caused by immune cell trapping. In this study, the impact of peripheral blood mononuclear cells (PBMC) on H. contortus larvae in the presence or absence of autologous serum was measured by larval ATP. Viability of larvae was tested by measuring fecal egg count (FEC) after infecting susceptible sheep with PBMC-exposed larvae. Larvae exposed to STC-derived or Suffolk (SUF)-derived PBMC had lower $(P<0.001)$ ATP than live larvae $(0.12$ $\mu \mathrm{M}$ ATP and $0.16 \mu \mathrm{M}$ ATP) $(0.27 \mu \mathrm{M}$ ATP $)$. Larvae exposed to PBMC from both breeds were greater than dead larval ATP $(0.03 \mu \mathrm{M}$ ATP $)(P<0.001)$. Larval ATP was lower when exposed to STC-derived PBMC with serum $(0.11 \mu \mathrm{M}$ ATP) than SUF-derived PBMC with serum $(0.23$ $\mu \mathrm{M}$ ATP $)$ or live $(0.22 \mu \mathrm{M}$ ATP $)(P<0.001)$. There was no significant difference between live larvae and larvae treated with SUF-derived PBMC with serum. Taken together, these data indicate a cellular response alone is capable of significantly lowering larval ATP. However, the addition of serum to SUF-PBMC failed to reduce larval ATP, suggesting differences in humoral response in mediation of $H$. contorus. 


\section{Acknowledgements}

Firstly, I'd like to thank my advisor Dr. Scott Bowdridge for taking a chance on me and giving me the opportunity to pursue my Master's degree. Dr. Bowdridge has been an incredible mentor. He has pushed my ability to think critically, challenging me become a better scientist and encouraging me to ask my own questions. In the past two years he helped me become more confident and independent, creating a framework lasting success. Because of this, my experience here has helped me grow and achieve more than I thought possible.

This research would not be possible without the hard work and support of my labmates Crista Crawford, Javi Garza, Taylor Harrison, Jesica Jacobs, Denzel Middleton, Brynnan Russ and Melissa Wise. Each of these individuals have helped shape my time here at WVU, guiding me as I learned how to navigate graduate school and also imparting their knowledge of livestock and farming. They have given countless hours of their time, lending a hand at the farm or in the lab. More than that, however, they have been my closest friends, and without them graduate school not be the same. Never before in my life have I had such a sense of comradery and understanding that we're all in this journey together. It is with their support that I've been successful as a student.

Making the decision to return to school wasn't easy after taking many years off following graduation with my undergraduate degree. But it was with the support of my family that pushed me to move to West Virginia. My parents have always provided unwavering love and support in all of my endeavors, continually cheering me on. My brothers, Andrew and Stephen, have continued to be examples in my life, encouraging me to take risks that drive me forward. Not only have they both been an inspiration, they are also my best friends whom I look up to with great respect and I wouldn't be here without their support. Lastly, I'd like to thank my Uncle Mark Teets for believing in me enough to make the phone call that started it all. The Teets family has been a home away from home, while I live here in West Virginia. 


\section{Table of Contents}

Acknowledgements ....................................................................................................... iii

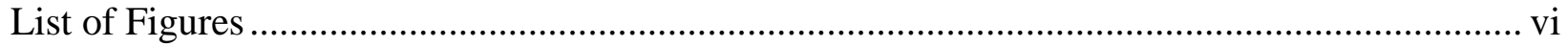

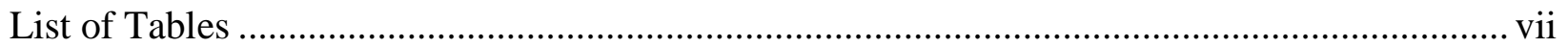

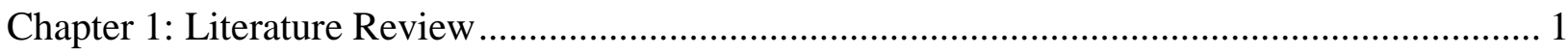

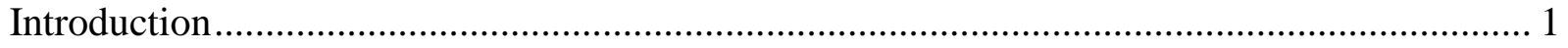

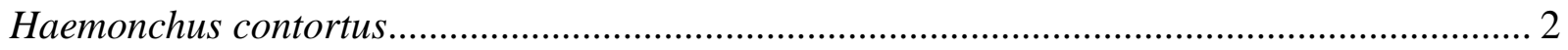

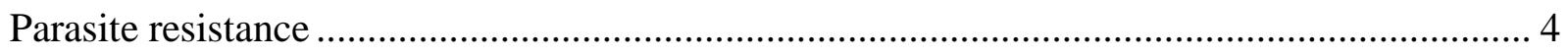

Immunological response to helminth parasite infection ...................................................... 7

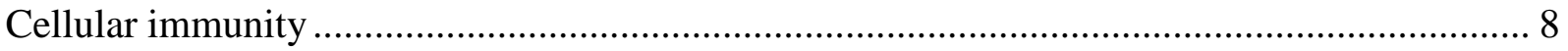

Innate effector cells: eosinophils, mast cells, neutrophils, macrophages and innate ................ 10

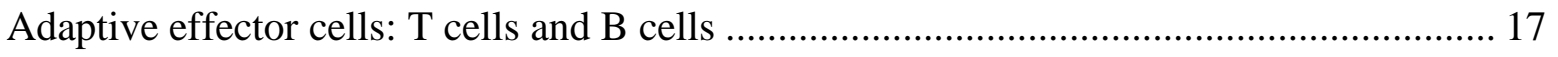

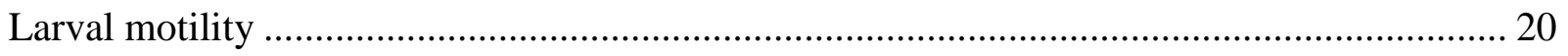

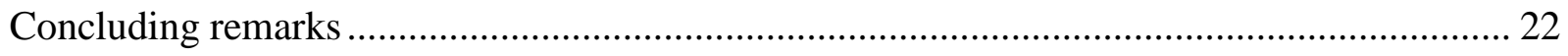

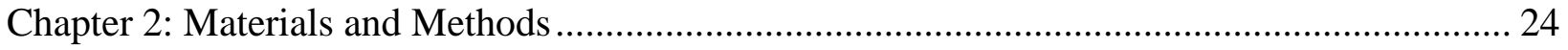

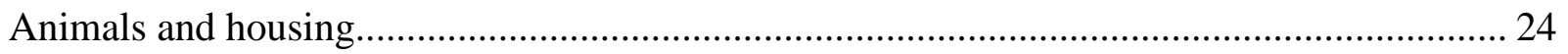

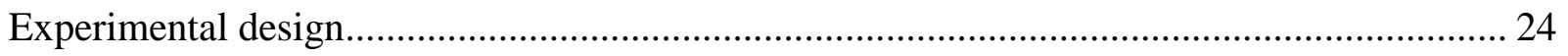

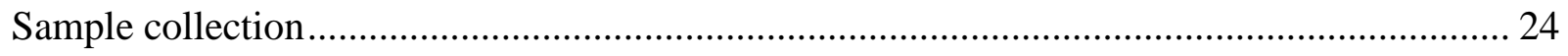

Separation of immune cells from blood................................................................................. 24

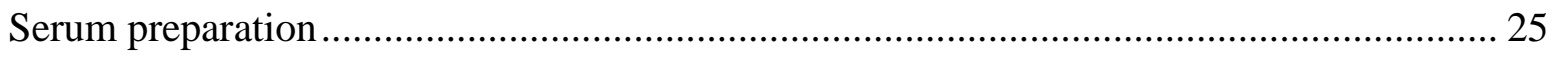

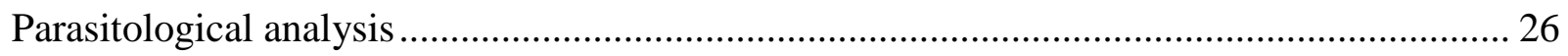

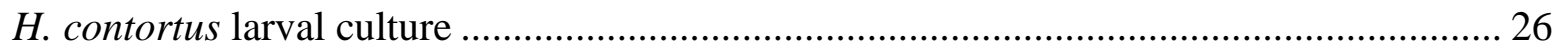




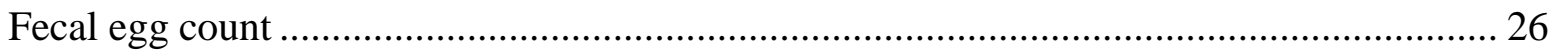

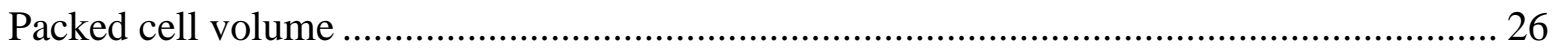

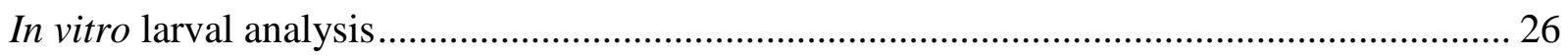

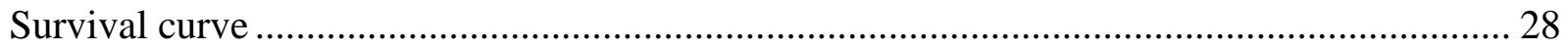

Preliminary infection of lambs using PBMC-exposed larvae.................................................. 28

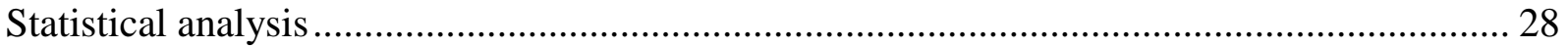

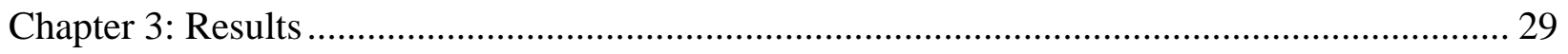

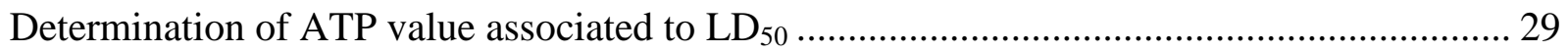

Effect of breed and immune status on larval ATP after exposure to PBMC ............................. 29

Effect of autologous serum on larval ATP following exposure to PBMC …………............... 30

Larval infectivity following exposure to PBMC from different breeds ................................... 31

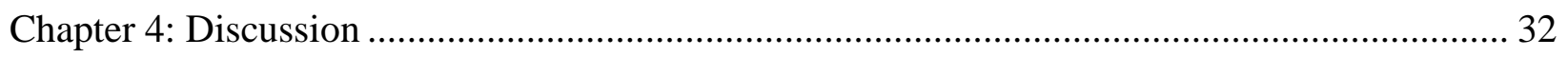

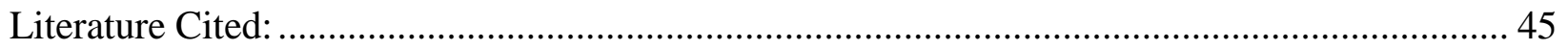




\section{List of Figures}

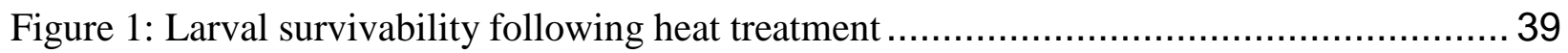

Figure 2: Larval ATP concentration after exposure to PBMC from SUF or STC sheep.......... 40

Figure 3: Larval ATP following culture with PBMC and autologous serum. ..................... 41

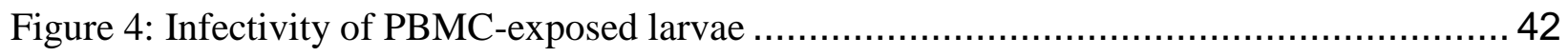




\section{List of Tables}

Table 1: Larval ATP concentration after exposure to PBMC ….......................................... 43

Table 2: Larval ATP concentration following incubation with PBMC and autologous serum ... 44 


\section{Chapter 1: Literature Review}

\section{Introduction}

Gastrointestinal trichostrongylid (GIT) parasites present a global animal health challenge, further amplified by development of anthelmintic resistance. Overuse of anthelminthics as a primary means of parasite control has resulted in resistant worm populations requiring development of alternative control methods for livestock producers. Of these GIT, Haemonchus contortus is the most pathogenic species affecting commercial sheep in the United States, causing anemia and complications that can quickly lead to death in severely affected animals (Howell et al., 2008). Incorporation of parasite-resistant sheep, such as St. Croix Hair sheep, is a reasonable approach to improving control of parasite.

St. Croix hair sheep are not typically considered desirable commercial sheep due to low carcass weights and slow growth rate when compared to conventional wool breeds. However, these sheep demonstrate a remarkable ability to clear a parasitic infection of $H$. contortus without anthelminthic drug treatment and, therefore, are considered parasite-resistant (Courtney et al 1985; Gamble and Zajac, 1992; Vanimisetti et al, 2004; MacKinnon et al, 2010; Bowdridge et al, 2015). St. Croix sheep produce a rapid and greater cellular immune response to $H$. contortus as compared to parasite-susceptible breeds, which helps prevent establishment of adult worms in the abomasum (Bowdridge et al, 2015). Infection with $H$. contortus induces a T-helper type 2 (Th2) response in the host, with increased expression of IL-4 and IL-13 genes, along with recruitment of eosinophils, mast cells and globule leukocytes in the abomasal lymph node and mucosa (Lacroux et al, 2006). Evidence also supports an essential role for adaptive immune cells in parasite resistance. An increase in tissue CD4+ T cells was observed by day two of challenge infection and an increase in $\mathrm{CD} 45 \mathrm{R}+\mathrm{B}$ cells was observed by day five after challenge 
(Robinson et al., 2010). Early influx of innate and adaptive immune cells indicates a role for immune cells in limiting larval establishment in sensitized sheep. Therefore, differences between parasite resistant and susceptible sheep might hinge on their ability to recruit cells to the abomasum early during $H$. contortus infection.

Larval motility, measured by path length, velocity and acceleration (Holt et al., 2015) can be signficiantly reduced, which suggests an immune cell role mediating larval establishment. Commonly, larval death is described as a combination of immobility and outstretched bodies with non-refractive internal structures (Chen et al., 2014). However, this standard fails to empirically quantify death and may not be an appropriate measure in this system. Therefore, experiments in this thesis are aimed to quantify larval death after exposure to immune cells to further characterize cell-mediated response to $H$. contortus in St. Croix hair sheep. Elucidation of cellular responses in larval death in parasite-resistant sheep is important for development of strategies to manage Haemonchosis in ruminants.

\section{Haemonchus contortus}

Gastrointestinal trichostrongylid (GIT) parasitic infections affect small ruminants worldwide and present a global economic challenge. According to the USDA National Animal health Monitoring System, GIT are the most frequently reported problem for producers in the United States, with 74\% reporting GIT present in their sheep for 15 years (USDA, 2001). While varying GIT parasites infect sheep, the virulence and widespread presence of $H$. contortus have made it one of the most important parasites in small ruminants (Alba-Hurtado and MunozGuzman, 2013).

The nematode parasite $H$. contortus belongs to the order Strongylida and is a member of the Trichostrongyloidea family. Haemonchus contortus adult worms reside in the abomasum of 
sheep and goats. Adult worms have a small, specialized buccal lancet, which is used to pierce host's abomasal mucosa and feed on blood. Female $H$. contortus have white ovaries wrapped around blood-filled intestine, giving them their "Barber-pole" appearance and associated pseudonym. Male worms are much smaller and possess an asymmetric dorsal copulatory bursa. Adult worms reproduce sexually in the abomasum, and eggs are shed in feces into the environment.

Haemonchus contortus follows a direct lifecycle with no intermediate host. Eggs undergo development in the environment in first stage larvae and molt twice before becoming infective third stage larvae $\left(\mathrm{L}_{3}\right)$ between five and eight days under optimal conditions. Larvae thrive in warm, humid environments. Sheep acquire an infection through ingestion of $\mathrm{L}_{3}$ while grazing on contaminated pasture. Water movement up grass blades during morning and evening dew transport larvae to the tips of grass, and it is also when sheep most actively graze, ensuring ingestion by the host. In more temperate regions, hypobiosis allows $\mathrm{L}_{3}$ to survive winter, when conditions increase their susceptibility to desiccation (Gibbs, 1973). During this period, consumed larvae are metabolically arrested in the host. When climatic conditions become favorable, larvae resume development into the adult stage. Under normal conditions, following ingestion, larvae molt and exsheathment occurs within the first 48 hours as the digesta passes through the forestomach, arriving at the abomasum (Roberts and Janovy, 2005). Depletion of host blood supply begins within seven days after consumption of larvae. Larvae develop to stage $4\left(\mathrm{~L}_{4}\right)$ and form a buccal lancet permitting blood feeding. After three days, $\mathrm{L}_{4}$ molt for a final time and become fully mature adults. From 14 to 21 days after initial infection, mature adult worms mate and produce eggs. 
Larval presence initiates a multitude of physiologic changes within the host. Symptoms of Haemonchosis include anemia, emaciation, edema and intestinal disturbances resulting in weakness, lack of growth and poor body and wool conditions. Presence of larvae in the abomasum induces glandular hyperplasia and inflammatory cell infiltration, along with increased $\mathrm{HCl}$ secretion decreasing abomasal $\mathrm{pH}$. Decreased $\mathrm{pH}$ in turn reduces digestion of protein and increases mucosa permeability (Alba-Hurtado and Munoz-Guzman, 2013) resulting in reduced nutrient absorption. Anemia is characterized by reduced packed cell volume (PCV) and lack of redness in mucosal membranes. Blood loss due to the hematophagy is estimated to be $0.05 \mathrm{~mL}$ per worm (Clark et al., 1962). Adult worms deplete nearly one fifth of total circulating erythrocyte volume in a lamb daily, whereas adult sheep may lose up to one tenth of their erythrocyte volume (Georgi and Whitlock, 1967). Edema results from the lack of plasma proteins and hyperprotenimia, allowing fluids to build up causing what is referred to as "bottlejaw." Typically, younger sheep are most affected by $H$. contortus infection, but other factors, such as nutrition and genetics, may influence the animal's response to infection. If the host cannot regenerate red blood cells to compensate for blood loss during infection, the severity of hemorrhage can quickly lead to iron deficiency and inability to deliver oxygen to tissues, leading to death. However, animals that are able to fight off infection can develop immunological memory and effect a self-cure.

\section{Parasite resistance}

In general, parasite resistance has been defined as the host's ability to resist establishment of the parasite and modify its egg production (Gray, 1995). Resistance is assessed by fecal egg count (FEC), which measures eggs per gram (epg) of feces, but FEC is limited as it does not always accurately measure host worm burden. Exposure to pasture and level of pasture 
parasitism can alter selection for FEC in animals, as samples taken at weaning may not be reflective of lifetime parasite resistance. To improve accuracy, FEC must be measured multiple times over a grazing season and across generations to be used in genetic evaluation (Woolaston and Piper, 1996; Ortolani et al., 2013). Heritability of selection for reduced FEC is low and variable, calculated at 0.2-0.6 (Vanimisetti et al., 2004; Laurenson et al., 2012), which does not reliably result in resistant offspring. Despite the limitations, it remains a useful tool to evaluate and identify parasite resistant sheep.

While PCV is often associated with $H$. contortus infection in sheep, PCV has lower heritability than FEC due to greater impact by environmental (Vanimisetti et al., 2004). In a study evaluating the performance of hair sheep, composite breeds to crossbred Dorset and Dorper wool lambs, Dorper sheep had the highest PCV when compared to Dorset or even Katahdin, St. Croix or Barbados Blackbelly breeds. Although Dorper had greater PCV levels they did not have greater resistance to $H$. contortus or ability to clear infection (Vanimisetti et al., 2004). Although PCV and FEC provide insight into the response and nature of infection, those measures fail to completely elucidate underlying mechanisms resulting from differences of values.

Breeding for parasite resistance is an alternative method of helminth control that reduces the need for anthelmintic treatment. While factors such as age, sex and nutrition influence level of parasite infection, natural resistance occurs in some breeds of sheep (Gamble and Zajac, 1992; MacKinnon et al, 2009). Haemonchus contortus thrives in tropical, subtropical and temperate regions that experience optimal warm, wet conditions; breeds of sheep originating from these regions have been exposed to consistent parasitic challenge and have developed natural resistance (MacKinnon et al., 2010). Breeds such as Florida Native, Barbados Blackbelly and 
St. Croix repeatedly demonstrate greater resistant to gastrointestinal nematodes than conventional wool breeds (Gamble and Zajac, 1992) based on FEC data. Notably, Barbados Blackbelly and St. Croix have consistently higher blood PCV and lower FEC after exposure to H. contortus when compared to Dorset or Rambouillet wool breeds (Courtney et al., 1985; Zajac et al., 1990; Vanimisetti et al., 2004). Concomitantly with marked differences in PCV and FEC, immunologic responses in hair sheep are more robust and are able to prevent establishment of adult $H$. contortus (Bowdridge et al., 2015).

Most notably, St. Croix hair sheep display remarkable resistance to $H$. contortus, with consistently lower FEC and higher PCV than other breeds (Courtney et al., 1984; Notter et al., 2003; Vanimisetti et al., 2004; MacKinnon et al, 2010). This has been demonstrated following both natural and artificial infection with H. contortus; St. Croix hair sheep have been reported to have $99 \%$ fewer worms recovered from the abomasum when compared to Dorset lambs (Vanimisetti et al., 2004), suggesting a higher level of acquired resistance. Abomasal lymph nodes from infected hair sheep were heavier with significant increase in immune cells than those of infected wool sheep (MacKinnon et al, 2010). After repeated larval infection, hypersensitized sheep have shown a significant inhibition of larval establishment of $H$. contortus in tissue cultures, suggesting a greater and more potent immune response (Kemp et al, 2009). Therefore, St. Croix are an ideal model for the evaluation of immune mechanisms of GIT resistance.

With consistently higher PCV, lower FEC and faster $H$. contortus clearance of especially following challenge infection, St. Croix are an example of GIT resistance. Mechanisms of resistance have been linked with mediation through protective immune responses (Patel et al., 2009). Gene expression analysis of gut mucosal tissues comparing resistant and susceptible breeds of sheep following infection with $H$. contortus further confirmed breed differences. 
Following a priming infection, resistant sheep displayed increased expression of genes related to tissue repair and cell migration in the abomasal tissue and local lymph nodes (MacKinnon et al., 2009). Macrophages, granulocytes and CD4+ T cells increase following infection with nematode parasites. Resistant sheep, like St. Croix expressed high levels of markers of early inflammatory response, whereas parasite-susceptible sheep showed delayed response and expression of markers consistent with chronic inflammation (Ingham et al., 2008).

\section{Immunological response to helminth parasite infection}

Immunity begins on an innate cellular level in the host, but also relies on adaptive immunity components to effectively clear the parasite. Generally, an immune response to helminth infection is characterized as a T helper 2 (Th2) response, which differs in the pattern of cytokines produced than does a T helper 1 (Th1) immune response. After infection, a cascade of events in response to a helminth infection plays a dual role in pathogen elimination and contributes to wound healing. What distinguishes resistant breeds from susceptible breeds, however, is early recognition of parasite infection inducing a Th2 response to drive worm expulsion (Gamble and Zajac, 1992).

In contrast to Th2 response, the Th1 response is associated with parasitic survival and increased host susceptibility (Else and Finkelman, 1998). Lower doses of infective nematodes can activate Th1 responses, resulting in secretion of IL-2, IFN-gamma and TNF-beta (Bancroft et al., 1994). In resistant BALB/c mice, which predominantly mount a Th2 response, infection with low levels of Trichuris muris resulted in an up-regulation of IgG2a and IFN-gamma production, which are characteristic of a Th1 response, and down-regulated cytokines associated with the Th2 response (Bancroft et al, 1994). At this low level of infection, eggs matured and established into adult worms while in what otherwise would be considered resistant hosts 
(Bancroft et al., 1994). Th2 type responses contribute to resistance and an animal's ability to clear a helminth infection, the Th1 type response is associated with inducing delayed-type hypersensitivity reactions (Romagnani, 1991) and an animal's inability to eliminate helminth infection.

Breeds of sheep showing a higher resistance to a $H$. contortus infection expressed cytokine genes typically associated with a Th2 response, such as IL-4, IL-5, IL-10, IL-13, and Arglin the abomasal lymph node cells (Meeusen et al., 2005; Terefe et al., 2007a; Craig, 2007), which act to mediate the host's protective response and control inflammation. Adult worm expulsion and larval impairment is reliant on this host protective response (Anthony et al., 2007). Cytokine production that determine effector function influence immunopathology and confer protection against disease (Romagnani, 1991). Localized wound repair also results from Th2 type polarization (Anthony et al., 2007). These events drive an influx of peripheral and tissue immune cells. Additionally, B cells secrete more IgA and IgE as migrating cells traffic through the local lymph tissue (Romagnani, 1991). More recently, group 2 innate lymphoid cells (ILC2) have been implicated in aiding the response to parasitic helminth infection, which contribute to the type- 2 response, producing high levels of same cytokines and promoting tissue repair (Oliphant et al., 2014). Taken together, studies on immune mediated resistance suggest that breeds of sheep that naturally expel $H$. contortus are reliant on a greater cellular immune responses (Bowdridge et al., 2015; Ortolani et al., 2013).

\section{Cellular immunity}

Resistance to gastrointestinal nematodes relies on changes in mucosal tissue and lymphoid tissue, allowing for the development of immunity. These changes include mucosal mast cell hyperplasia, eosinophilia, increase in mucus production and production of specific 
antibodies (Balic et al., 2000a). Innate immune cells begin to attack larvae as they migrate through the digestive system into the abomasum. As larvae migrate, mast cells, neutrophils, eosinophils and macrophages infiltrate the site of infection. Recognition through toll-like receptors signal cells to mount an initial response to helminth infection (Balic et al, 2000a). However, changes in host internal environment cue larvae to molt and shed their cuticles. Although immune cells are activated in response to $H$. contortus antigens, different surface molecules are expressed at different stages during the lifecycle. These relatively quick changes in expression between parasite life stages can make it difficult for the host to respond appropriately and aids in immune evasion (Lacroux et al., 2006; Alba-Hurtado and Munox-Guzman, 2012).

Both damage caused by blood feeding and secreted larval proteins promote an innate response and act as damage-associated molecular patterns (DAMPs) recognized by the immune system (Tizard, 2012). Antigen presenting cells (APC) at the site of infection are able to sample larval antigen, migrate to local lymph nodes, where they present antigen to CD4+ T helper (Th) cells. APCs, like DCs and macrophages, bridge the innate and adaptive immune system, which allows for the development of specificity and memory. Cells involved in adaptive immune responses include antigen specific $\mathrm{T}$ lymphocytes and $\mathrm{B}$ cells that produce $\operatorname{IgE}, \operatorname{Ig} \mathrm{A}$ and $\operatorname{IgG}$ antibodies (Schallig, 2000; Shakya et al., 2009; Miller, 1984). H. contortus specific antibodies increase 2-4 weeks after infection and are negatively related to worm counts (Kooyman et al., 1997; Lacroux et al., 2006). Most sheep, even susceptible breeds, develop some resistance to $H$. contortus after repeated larval infection; however, hypersensitization results in significant inhibition of larval establishment (Kemp et al., 2009; Miller et al., 1983).

Resistant sheep, infected with $H$. contortus, display a rapid and robust immune response, which suggests that this early and strong Th2 type response acts against larval stages of the 
parasite, preventing establishment. A primary infection produces an influx of innate immune cells, which drives the polarization of adaptive $\mathrm{T}$ cells towards a Th2-response. Eosinophils, CD4+ T cells and B-cells, along with increased lymph node size as early as 5 days after infection have been observed (Balic et al., 2000). Following primary infection in resistant Barbados Black Belly lambs compared to INRA 401 susceptible lambs, an elevated Th2-response persisted for much longer in the resistant lambs. During primary infection these lambs showed a significantly lower FEC, abomasal worm count and smaller adult female worm size (Terefe et al., 2007). Susceptible breeds can build immunity following a primary infection, resulting in a dramatic reduction in FEC and increase in immune responsiveness following challenge infection. On challenge infection, total worm burden and FEC were reduced in susceptible breeds, where resistant breeds showed no difference from primary infection (Terefe et al., 2007; Zajac et al., 1990). However, INRA 401 sheep respond as early as 3 days after challenge infection and are able to clear $H$. contortus sooner when compared to susceptible lambs under the same conditions (Lacroux et al., 2006). Taken together, resistance relies heavily on the ability to mount a parasite-specific cell-mediated immune response, driving development of immunological memory.

Innate effector cells: eosinophils, mast cells, neutrophils, macrophages and innate lymphoid cells

\section{Eosinophils}

Eosinophils are an effector cell population associated with gastrointestinal helminth infection. When tissues are injured, eosinophils act to aid in tissue remodeling and clear debris (Anthony et al., 2007). Infective larvae activate eosinophils and cause migration to the site of infection through IgA cell surface receptors, complement and IL-5 resulting in decreased larval 
establishment and direct damage of parasitic larvae in vitro (Prussin and Metcalfe, 2003). Eosinophils are activated by the Th2 cytokine IL-5 and act in an antibody-dependent manner to induce target toxicity (Shakya et al., 2009). Additionally, eosinophils surround helminth larvae in tissues during primary infection (Meeusen et al, 2005). Shortly after helminth infection, eosinophil counts increase in both blood and tissues. These cells can even display a targeted response towards parasites, accumulating around larvae in vivo and in vitro (Rainbird et al., 1998).

Eosinophils, along with mast cells, have been found in greater densities in abomasal tissues of resistant lambs when compared with susceptible lambs (Gill et al., 2000). In the presence of anti- $\mathrm{L}_{3}$ surface antibody, eosinophils directly inhibit $H$. contortus larval mobility in vitro leading to increased larval killing (Rainbird et al., 1998). When juvenile H. contortus $\mathrm{L}_{2}$ larvae were incubated with $H$. contortus $\mathrm{L}_{3}$ (HcsL3) antibodies in the presence of eosinophils, larval death was again observed (Rainbird et al, 1998), indicating direct targeting of the infective stage.

Other studies have found that eosinophil density is much higher in ovine tissues, as early as three days and as late as 42 days post exposure to H. contortus (Shakya et al., 2009). A longlived phenotype has been supported in murine models; where eosinophils increase between day four and seven of infection with $N$. brasiliensis, but returned to baseline by three months post inoculation (Chen et al., 2014), suggesting that larval presence activates eosinophil migration to the infection site to aid in reduced larval establishment and thereby reducing tissue damage.

Despite the ability of eosinophils to directly immobilize and kill infective $H$. contortus larvae in vitro (Rainbird et al., 1998), eosinophils may not have a direct effector function in 
parasite resistance. Further studies demonstrated that the number of circulating and tissue eosinophils was not different between naïve, primed or challenged lambs (Huntely et al., 1995; Schallig et al., 1997a; Terefe et al., 2007), suggesting they may contribute, but are not essential to clearance of $H$. contortus. In mice, IL-5 depletion and the absence of eosinophils, there was no effect the host's ability to expel adult worms during a primary infection (Meeusen and Balic, 2000; Herndon and Kayes, 1992). Additionally, eosinophil depletion did not significantly alter development of Th2 responses to helminth infection (Brunei et al., 1999)

\section{Mast cells}

Mast cells are activated by Th2 cytokines such as IL-3, IL-4, IL-9 and IL-10. During helminth infection, mast cell high-affinity receptors for the Fc region (FceR1) binds antibody $\operatorname{IgE}$ produced by B cells. Binding IgE triggers degranulation and the release of nitric oxide (NO) and histamine by mast cells, which can also release cytokines IL-13 and IL-33 and with proteases. These mechanisms associated with Th2 differentiation, as well as the increased permeability in gut epithelium during infection, reduce worm survival and contribute to worm expulsion.

Numbers of mucosal mast cells (MMC) are altered in response to primary or challenge infections. Mucosal mast cells were elevated during priming infection with $H$. contortus and even more so during challenge infection (Schallig et al., 1997a). Repeated infection with $H$. contortus larvae resulted in mast cell hyperplasia, inducing mucosal mastocytosis and the inability of larvae to establish in the abomasal mucosa due to the release of granule-specific sheep mast cell proteinase (Huntley et al., 1992). However, when sheep were allowed to rest, un-stimulated with larvae, for 84 days, resistance to the helminth was lost and mast cell proteinase concentration was reduced markedly (Huntley et al., 1992). 
Treatment with anti-IL-3 and anti-IL-4 monoclonal antibodies (mAb) in mice resulted in significantly decreased mastocytosis, but the reduction in mast cell hyperplasia did not prevent worm expulsion (Madden et al., 1991). However, Ortolani et al. (2013) demonstrated MMC increased in correlation with $H$. contortus infection in sheep. Associated environmental changes in the host might contribute to a non-specific inflammatory response or mast cells might be directed towards protective response to primary infection.

\section{Neutrophils}

Neutrophils are rapid responders to infection, phagocytizing pathogens such as bacteria and viruses, clearing the body of cellular debris resulting from pathogenic invasion. During helminth parasitic infection, neutrophils infiltrated tissues within the first 12 hours (Bass and Szejda, 1979) and were most abundant cell type during early infection of $H$. contortus (Ortolani et al., 2013). Signaling through IL-4 receptor $\alpha$ (IL-4R $\alpha$ ) influenced recruitment of neutrophils to the helminth site of infection (Chen et al., 2012). When IL-4R $\alpha$ was inhibited, neutrophil accumulation decreased and pathology associated with $N$. brasiliensis infection increased (Chen et al., 2012). While neutrophils responded early, neutrophil numbers returned to base line in the abomasal mucosa by day 21 following $H$. contortus infection, indicating an association with larval stages (Shakya et al., 2011).

Though it is unlikely that neutrophils directly mediate clearance of worms, their role in Th2 immunity should not be overlooked in immune response against nematode parasites. Neutrophils activated during parasitic infection interacted with macrophages, up-regulating antihelminth macrophages and adhesion molecules (Chen et al, 2014). Long-lived effector macrophages were induced through the up-regulation of IL-4R $\alpha$ (Allen, et al., 2015). Depletion of neutrophils in mice greatly impaired effector macrophages ability to damage parasites, 
suggesting that neutrophils played a vital role in priming alternatively activated macrophages associated with helminth infection (Chen et al., 2014). The reduced ability suggests that neutrophils contribute to host protection against parasitic larvae through signaling pathways.

\section{Macrophages}

Classically activated macrophages are typically considered major players in a Th1 response, where they are critical in responding to invasive bacteria and viruses. This macrophage phenotype is responsible for engulfing and clearing debris and are differentiated by production of nitric oxide synthesis (iNOS), ultimately generating nitric oxide (NO) and TNFa. Production of Th2 cytokines, IL-4, IL-13 and IL-10 triggers differentiation of what commonly are referred to as alternatively activated macrophages (AAM). These AAM are distinguished by expression of arginase-1 (Arg-1) and IL-4R $\alpha$ without iNOS production (Anthony et al., 2006). In a Th2 setting, AAM acts to regulate immune responses, promote wound healing and might also provide a protective role during helminth infection.

Signaling is accomplished through IL-4R $\alpha$, which is required for the development of effector AAM, reducing inflammatory cytokine IL-17 and simultaneously enhancing IL-10 production and thereby stimulates AAM development (Chen et al., 2012). In this way, AAMs act to regulate the immune response during helminth infection by production of IL-10 and IL-13, down regulating Th1 type immune response. In addition, these macrophages recruit additional cell populations to help mediate parasitic invasion, which also produce cytokines sustaining Th2 responses.

Not only do AAM suppress inflammatory cytokines, but also they contribute to tissue repair, fibrosis and clearance of debris (Martin and Leibovich, 2005; Wynn and Barron, 2010). Helminth parasites can cause extensive tissue damage resulting in release of proteolytic enzymes 
that damage surrounding cells (Kreider et al., 2007). During helminth infection, AAMs increased production of proteins, such as fibronection, collagens and matrix metalloproteinase (MMP), which are associated with tissue repair (Gratchev et al., 2005). Granulomas composed of masses of myeloid lineage cells (Mornex et al., 1994) surround invading larvae and upregulate Th2 immunity. Granuloma formation contributes to wound repair by isolating invading parasitic larvae or eggs, thereby reducing surround tissue damage.

Mice deficient in IL-4R $\alpha$ showed a decreased capacity of macrophages to bind to and immobilize parasites, resulting in increased ATP levels in the worms (Chen et al., 2014). Similarly, when mice infected with Heligmosomoides polygrus (H. polygrus) were depleted of macrophages by the administration of an arginase inhibitor, larval motility increased, along with increased adult worm burden (Anthony et al., 2006). Observed reduction in larval death in the absence of AAM supports their role in mediating helminth infection and, thereby, contributing to Th2 host response necessary for parasitic clearance.

Macrophages collaborate with neutrophils to enhance in vitro killing of helminth parasites. In mice, infection with Strongyloides stercoralis (S. stercoralis) induced AAM capable of killing larvae in vivo and in vitro in the presence of neutrophils (Bonne-Annee et al., 2013). Similarly, during N. brasiliensis infection of mice primed with neutrophils from parasite-infected mice were able to rapidly mediate nematode damage and clearance (Chen et al., 2014). When using ATP as a measure of larval death, primed AAM demonstrated greater larval adherence and significantly reduced larval ATP in vitro (Chen et al., 2014), thereby enhancng larval killing. In contrast, using classically activated macrophages did not result in larval death, either in vivo or in vitro models, after exposure to neutrophils (Bonne-Annee et al., 2013). 
Macrophages activated during helminth infection migrated to intestinal epithelial submucosa after challenge infection, when CD4+ $\mathrm{T}$ cells developed a memory phenotype (Anthony et al., 2006). Production of IL-4 by those CD4+ T cells was necessary for activation of AAM and parasite expulsion. When AAM differentiation and Arg-1 function were inhibited by depletion of $\mathrm{CD} 4+\mathrm{T}$ cells, protective immunity was lost, and hosts were unable to expel parasites (Anthony et al., 2006), suggesting a strong link between Th2 responses and AAM in developing full protection against helminth infection.

\section{Innate lymphoid cells, class 2}

Similar to T cells, innate lymphoid cells (ILCs) are of lymphoid lineage, but they lack T cell receptor (TCR) or B cell receptor (BCR), thus foregoing thymic selection. These cells are not antigen-specific and do not respond in an antigen-specific manner. Despite this, type 2 ILCs (ILC2) demonstrate a strong effector response and produce Th2 cytokines, which ultimately may contribute to clearance of helminth infection (Guo et al., 2015). Type 2 ILC express the transcription factor GATA-3 and produce IL-13 as well as IL-5, distinguishing them from type 1 and type 3 ILC. Several studies have demonstrated that ILC2 are present early during helminth infection and occurs before expansion of an adaptive Th2 response (Oliphant et al., 2014). Since Th2 cells are typically rare in naïve animals, as they have not developed a memory response, ILC2 could be an early and dominant source of polarizing cytokines contributing to adaptive immunity (Oliphant et al., 2014; Guo et al., 2015).

When IL-13 deficient mice were given an infection with $N$. brasiliensis, the mice were unable to expel worms. However, when ILC2 were transferred into IL-13 deficient mice, Th2 cell responses were restored (Neill et al., 2010). Another study showed that delayed cytokine production by Th2 cells was observed in IL-25 deficient mice infected with $N$. brasiliensis, 
which lead to inefficient worm expulsion (Fallon et al., 2006). When recombinant IL-25 was administered, ILC2 cell populations appeared and lead to rapid worm expulsion, dependent on cytokine, but not on either T or B cells (Fallon et al., 2006). Moreover, this population of induced non-T and non-B cells provided the essential cytokines to drive Th2-mediated worm expulsion (Fallon et al., 2006).

\section{Adaptive effector cells: $\mathbf{T}$ cells and $B$ cells}

\section{T cells}

Genetic resistance of sheep to GIN is reliant on a multitude of host responses, including immune cell proliferation and the production of specific antibodies. T cells have two main subsets, $\mathrm{CD} 4+\mathrm{T}$ cells and $\mathrm{CD} 8+\mathrm{T}$ cells. Of these, $\mathrm{CD} 4+\mathrm{T}$ helper cells can be delineated into Th1 and Th2 subsets, depending on the cytokine environment the $\mathrm{T}$ cell experiences during antigen presentation (O'Garra and Murphy, 1994). A Th2 cell develops in the presence of IL-4 and IL-13, inducing the IL-4R-alpha signaling pathway. These cytokines are associated with helminth infection and enhanced parasite clearance. Early expression of Th2 cytokines is essential in Th2 differentiation. Effector cells, such as eosinophils, basophils and mast cells, as well as AAMs, are responsible for producing and driving Th2 polarization during early helminth infection (La Flamme et al., 2012).

When CD4+ T cells were depleted in resistant lambs, globule leukocyte and eosinophil counts were not significantly lower than in control animals (Gill et al., 1993). However, depletion of CD4+ T cells impaired resistant lamb's ability to eliminate $H$. contortus, essentially abrogating host response to the parasite (Gill et al., 1993). These lambs also had a significantly higher FEC and worm burden than control lambs (Gill et al., 1993). In a similar study, effects associated with depletion of CD4+ $\mathrm{T}$ cells were greatest 14 days following infection (Karanu et 
al., 1997). Importantly, the lambs were exposed to $H$. contortus through two priming infections. A study using repeat-infected lambs, showed earlier expression of Th2 cytokines and were able to mobilize effector cells earlier than sheep receiving a priming infection (Shakya et al., 2009).

In a similar study, Peña et al. (2006) depleted CD4+ lymphocytes two days before experimental infection with $H$. contortus of naïve lambs. While depletion was not observed until day 9 following treatment, worm burden was higher than in control animals treated with $\operatorname{IgG}$ control antibody, and PCV was not significantly different (Peña et al., 2006). Nevertheless, this study demonstrated requirement of CD4+ T cells in genetic resistance, which was lost in lambs that were depleted of CD4+ T cells resulting in greater susceptibility to H. contortus (Peña et al., 2006). Alternatively, in this study, depletion of CD8+ T cells had no effect on FEC or worm burden in resistant lambs (Gill et al., 1993), specifically implicating CD4+ T cells in both acquired and genetic resistance of sheep to $H$. contortus.

To further characterize the role of CD4+ $\mathrm{T}$ cells, they help regulate the host adaptive immune response to helminths by producing cytokines, regulating cell recruitment. Mastocytosis is regulated by IL-3 and IL-4, induced by eosinophilia, both of which are a result of CD4+ $\mathrm{T}$ cell activation. In resistant lambs, depletion of CD4+ $\mathrm{T}$ cells caused a reduction in mast cell hyperplasia and tissue eosinophilia, which corresponds with an impaired ability to mount a response needed to clear $H$. contortus infection (Gill et al., 1993). CD4+ T lymphocytes also aid in the class-switch recombination of B cells, which are then able to produce antibodies to antigen.

\section{B Cells}

In any immune response, B cells function as antibody producers. After being activated by $\mathrm{T}$ cells, in secondary lymphoid tissues. Here activated $\mathrm{T}$ cells present antigen to $\mathrm{B}$ cells, 
which can then generate and release antibody (Liu et al., 2010). The hallmark cytokine of helminth infection, IL-4, enables immunoglobulin (Ig) E and $\mathrm{IgG}_{1}$ class switching. Similarly, IL-5, another Th2 associated cytokine, plays a role in IgA class switching. Release of IgE can amplify immune response by triggering mast cell degranulation and recruiting other Th2-type effector cells to the site of infection (Anthony et al., 2007).

Antibody production has been shown to be associated with the defense against $H$. contortus infection in parasite resistant sheep. Specifically in response to $H$. contortus, serum levels of $\operatorname{IgA}$, $\operatorname{IgE}$ and $\operatorname{IgG}$ were elevated in parasite resistant sheep (Meeusen et al., 2005; Lacroux et al., 2006). A study by Schallig (2000) showed increased IgG, E and A in response to H. contortus in parasite resistant sheep during infection. Antibodies can be produced during either priming or challenge infection, where IgA is produced in response to larvae and specific IgG1 and IgG2 is produced in response to adults (Schallig et al., 1994). Serum IgA, along with serum IgG1 and IgG2 levels, increased during priming infection, but quickly during early challenge infection, with overall serum antibody levels doubling from priming to challenge infection (Schallig et al., 1994). Furthermore, while circulating IgE levels were not different between parasite susceptible and resistant breeds, concentrations of IgE in lymph node extract was higher by 27 days after infection (MacKinnon et al., 2010). Resistant sheep also have higher levels of IgA as early as 3 days after infection with $H$. contortus, and it remained high for up to 21 days after infection, when compared to parasite susceptible sheep (MacKinnon et al., 2010).

Other models have been studied to elucidate the role of B cells in Th2 immunity, supporting a clear role of humoral immunity in parasite resistant breeds of sheep. Using $H$. polygrus to model gastrointestinal helminth infection, mice deficient in B cells were unable to 
expel parasites after a challenge infection (Liu et al., 2010). Additionally, production of antibody during the tissue-dwelling phase of $H$. polygrus infection was essential in protection from the parasite in secondary infection (Liu et al., 2010). On the other hand, when mice were depleted of B cells and given a challenge infection of $N$. brasiliensis, Th2 cell differentiation and response were not impaired (Liu et al., 2010). The difference between parasitic infections, however, may largely be due to the life cycle of each of the helminths addressed, where $H$. polygrus is strictly enteric and $N$. brasiliensis follows hepato-tracheal migration before establishing in the gut.

Together these studies indicate a role for antibody produced by B cells as an effector molecule contributing to parasite expulsion (Liu et al., 2010) and that antibody supports development of full protective immunity in parasite resistant sheep (MacKinnon et al., 2010); however, it is unlikely that antibody directly mediates parasitic infection.

Collectively, these studies demonstrated that differences between parasite resistant breeds and susceptible breeds of sheep relies on the ability of the sheep to develop a lasting immune response through both cellular immunity and the involvement of antibody. Despite the strong immune response, however, parasites have co-evolved with hosts to permit their survival and evade immune detection.

\section{Larval motility}

Parasitic species also have developed strategies to evade the immune system. Ingested infective stage larvae undergo molting, where they secrete different antigens at each stage, aiding their survival and the host's delayed response. Specific to H. contortus, when compared to other helminths, larval motility is a key survival strategy that allows for establishment. L4 stages of $H$. contortus inhabit the surface of the gastric mucosa rather than the gastric pits, which would 
otherwise provide protective isolation from host immune mechanisms (Balic et al., 2000). As larvae are left exposed and vulnerable, motility is essential for larvae to evade immune detection at damaged sites of the mucosa.

Maintaining larval motility is essential to success of parasite survival, which has led to the use of motility as a standard measure determining efficacy of chemotherapeutic drugs and other anthelminthic treatments. Anthelmintic drugs, like levamisole, act as paralytic agents causing muscle contraction immobilizing larvae (Martin and Le Jambre, 1979). To assess anthelmintic resistance, bioassays have been developed to detect motility. For in vitro assessment, agar gels were used to detect both anti-parasitic components in resistant sheep gastrointestinal mucus and also to demonstrate the inhibitory effects of anthelmintic (Kimambo and MacRae, 1988; Douch and Morum, 1994).

Inhibition rates of levamisole were compared to inhibition of larval motility using mucus from the gastrointestinal tract of resistant sheep. Mucus from challenge infected resistant sheep inhibited larvae by $93 \%$, whereas when treated with levamisole in vitro, larvae were completely immobilized (Douch et al., 1983). Similarly, mucus from lambs challenge-infected with Trichostrongylus colubriformis (T. colubriformis) significantly inhibited larval migration from agar gels when compared to corresponding mucus from parasite-free control animals (Kimambo and MacRae, 1988). Interestingly, mucus from resistant sheep lost their ability to immobilize larvae at the end of a 4 week post-challenge rest period (Kimambo and MacRae, 1988). In addition to agar gel bioassays, larval motility in response to anthelmintic treatment has been measured as the number of larvae crossing a 20- $\mu \mathrm{m}$ mesh screen (Rabel et al., 1994). While these methods may indicate perceived immobility, they do not indicate larval death. 
Bioassays of larval inhibition can define larvae either as either motile or non-motile, but the question remains as to the infectivity of non-motile larvae. In early experiments, larvae recovered from feces of resistant sheep between 24 and 28 hours after a challenge infection remained infective when given to susceptible, naive sheep (Douch et al., 1983; Elliott, 1981). Preliminary studies evaluating the effects of peripheral mononuclear cells (PBMC) (lymphocyte and monocyte populations) on $H$. contortus using this evaluative method of motility were unable to distinguish differences in larval motility when larvae were exposed to cells derived from sheep of different immune status and breed (Holt et al., 2015). Using advanced microscopic imaging and tracking, larval motility was quantified by measuring path length, velocity and acceleration of individual larvae in the presence of PBMC. After co-culture of larvae with PBMC from naïve Suffolk (SUF) sheep had reduced ability to immobilize larvae as compared PBMC from of either primed or naïve St. Croix hosts. Larvae exposed to naïve wool PBMC had significantly higher velocity and greater path length compared to all other groups (Holt et al., 2015). Additionally, lack of motility was associated with immune cell trapping, indicating an innate ability of St. Croix-derived immune cells to inhibit larval motility in vitro (Holt et al., 2015).

\section{Concluding remarks}

Together, these studies demonstrate a strong immune response to parasitic infection with gastrointestinal nematodes. Differences in natural resistance are evident when comparing breeds. Resistant breeds have an ability to generate a rapid cellular response and also a lasting memory response to parasitic infection with $H$. contortus. However, immune mechanisms that distinguish these breeds have yet to be fully elucidated. A critical need exists to determine the viability or infectivity of larvae after exposure to mononuclear cells obtained from parasiteresistant and susceptible breeds to better understand the role of mononuclear cell-induced larval 
death. Specifically, examining the response of cellular interaction with larvae and using immune cells from St. Croix hair sheep will aid in the understanding of immunological mechanisms involved in early larval rejection in sheep. Data collected from this research will provide information needed to develop advanced chemotherapeutics required to manage Haemonchosis in ruminants. 


\section{Chapter 2: Materials and Methods}

\section{Animals and housing}

Sheep used in this project were born and raised at the West Virginia University Animal and Veterinary Science Farm (Morgantown, WV) and were housed in the Sheep Research Barn which has a raised, expanded metal floor. This housing strategy eliminated potential exposure to H. contortus through fecal contamination, because feces from sheep fall through the expanded floor, separating infected feces from the animals' food source. All animals were limit fed 16\% CP corn-soybean concentrate with ad libitum grass hay and water. This study was approved by the Animal Care and Use Committee (ACUC 13-0308.1).

\section{Experimental design}

Ten St. Croix (STC) hair sheep and ten Suffolk (SUF) wool sheep were raised and kept on an elevated floor barn for the duration of the experiment. Four weeks after weaning, lambs of each breed were randomly assigned to one of two treatment groups: naïve or primed. Animals assigned to primed groups received a single oral dose of 10,000 Haemonchus contortus infective stage 3 larvae $\left(\mathrm{L}_{3}\right)$. Infection persisted for six weeks before infected animals were treated with Levamisole (Agrilabs, St. Joseph, MO) $(8 \mathrm{mg} / \mathrm{kg}$ ) and then allowed to rest for three weeks before blood collection. Animals assigned to naïve treatment groups received no infection and remained unexposed to Haemonchus contortus due housing on the raised floor. Fecal egg counts (FEC) were performed on all lambs during the priming infection and after deworming until all animals had an FEC of 0 before blood collection.

\section{Sample collection}

\section{Separation of immune cells from blood}

Whole blood samples were obtained via jugular venipuncture into $10 \mathrm{ml}$ vacutainer tubes treated with ethylenediaminetetraacetic acid (EDTA) (Tyco, Mansfield, MA), preventing 
coagulation. Samples were pooled by treatment and then centrifuged at $1,000 \times \mathrm{g}$ for 20 minutes at room temperature, buffy coats were collected and transferred into sterile $15 \mathrm{ml}$ centrifuge tubes and re-suspended in $1 \mathrm{ml}$ sterile phosphate buffered saline (PBS). Red blood cells (RBC) were removed by incubation with ACK lysis buffer (Lonza, Walkersville, MD). Then, white blood cells were carefully layered over sterile lymphocyte separation media (LSM) (SPG $1.077 \mathrm{~g} / \mathrm{ml}$; Corning, Manassas, VA) and centrifuged at $400 \times \mathrm{g}$ for 20 minutes at RT. Peripheral blood mononuclear cells (PBMC) were collected and counted using a Bio-Rad TC-20 automated cell counter, and then suspended in complete media containing RPMI-1640 with 2mM L-glutamine (GE Healthcare Life Sciences, Logan, UT), 10\% fetal bovine serum (FBS) (Corning, Corning, NY ) and penicillin-streptomycin antibiotic (Sigma Aldrich, St. Louis MO, USA). Suspensions were diluted to a concentration of $1 \times 10^{6}$ cells per $\mathrm{ml}$ for use in culture. Confirmation of lymphocyte and monocyte cell purity was confirmed by performing a manual cell differential count. Briefly, $100 \mu 1$ of cell suspension was loaded into a Cytospin chamber, concentrated onto a microscope slide using Cytospin 4 (Thermo Scientific) and then stained using CamCo Quik Stain (Cambridge Diagnostic Products, Fort Lauderdale, FL). Preparation of PBMC resulted in a cell population of greater than $99 \%$ mononuclear cells.

\section{Serum preparation}

Whole blood was collected via jugular venipuncture into $10 \mathrm{ml}$ untreated vacutainer tubes (Tyco, Mansfield, MA) and allowed to clot. Blood was then centrifuged at $750 \times \mathrm{g}$ for 20 minutes at $4^{\circ} \mathrm{C}$. Serum was removed and pooled by treatment group, and was sterilized through $0.22 \mu \mathrm{m}$ filters (Merck Millipore, Cork, Ireland). One $\mathrm{ml}$ of serum was removed and aliquoted in microcentrifuge tubes and stored at $-80^{\circ} \mathrm{C}$. 


\section{Parasitological analysis}

\section{H. contortus larval culture}

Feces were collected from $H$. contortus infected Suffolk wethers and then mixed with sterilized peat moss and activated charcoal and incubated for 7 days at $30^{\circ} \mathrm{C}$. Larvae were then collected using Baermann technique and stored in PBS $\left(\mathrm{pH} \mathrm{7.4)}\right.$ at $4^{\circ} \mathrm{C}$ for no longer than 3 months before use. Larvae were diluted to a concentration of $1,000 \mathrm{~L}_{3} / \mathrm{ml}$ in sterile PBS before use in in vitro assays.

\section{Fecal egg count}

Fecal egg counts were performed on each animal using Modified MacMaster's technique (Whitlock, 1948). Briefly, 2g feces were measured from each sample and homogenized with 28ml McMaster's Salt Solution (SPG $1.2 \mathrm{~g} / \mathrm{ml}$ ). The mixture was then passed through a double layer of cheese cloth, and loaded into McMaster's slider chambers (Chalex Corp., Portland, OR). Eggs within grid were enumerated, with the total egg count from two grids being multiplied by 50 to yield eggs per gram of feces.

\section{Packed cell volume}

Whole blood samples were collected from each animal via jugular venipuncture into $5 \mathrm{~mL}$ vacutainer tubes containing EDTA for pack cell volume (PCV) analysis. PCV was analyzed by filling heparin treated micro-hematocrit tubes (StatSpin, Westwood, MA) with blood samples and placed in a micro-centrifuge (StatSpin, Westwood, MA) for two minutes before digitally reading percentage of $\mathrm{RBC}$.

\section{In vitro larval analysis}

Cells from experimental animals were pooled by treatment group and diluted as outlined previously. Cell suspension $(500 \mu \mathrm{l})$ was added in triplicate to a 24 -well plate (Greiner CellStar, Frickenhausen, Germany) with an additional $400 \mu \mathrm{l}$ of complete media and $100 \mathrm{~L}_{3} \mathrm{H}$. contortus 
larvae added to each well for a total volume of $1 \mathrm{ml}$ per well. For experiments using autologous serum, $100 \mu 1$ serum replaced $100 \mu$ l of complete media and was added to each well for a total volume of $1 \mathrm{ml}$ per well. Plates were gently stirred before being placed into an incubator for 18 hours at $37^{\circ} \mathrm{C}$ with $5 \% \mathrm{CO}_{2}$, after which, supernatant was removed and replaced with $300 \mu 1$ Accumax $^{\mathrm{TM}}$ enzyme (Innovative Cell Technologies, San Diego, CA) to release cells from larvae and degrade 3-dimensional cellular projections. Larvae were then rinsed over $40 \mu \mathrm{m}$ cell strainers (Greiner BioOne, Frickenhausen, Germany) to achieve larvae without cells before being transferred to sterile micro-centrifuge tubes. An equal volume of CellTiter-Glo (Promega, Madison, WI) was added to each larval sample, and larvae were homogenized using a tissue homogenizer. Samples were then centrifuged at $1,000 \times g$ for 2 minutes, and $100 \mu 1$ of supernatant was plated into opaque walled flat-bottom 96-well microplate (Greiner CellStar, Frickenhausen, Germany). The luminescent signal was allowed to stabilize for 10 minutes before measuring using a luminometer (BioTek Instruments). Luminescence was measured using an integration time of 1 second per well.

An ATP standard curve was created using serial dilutions from $10 \mu \mathrm{M}-0.001 \mu \mathrm{M}$ of rATP (Promega, Madison, WI), and a blank standard of $0 \mu \mathrm{M}$ was measured using PBS. Standard values were plotted against luminescent values then fitted using a linear regression line. Experimental ATP concentrations were corrected by subtracting background luminescence, using a blank standard, and calculated using the standard curve performed for each replication. Mean ATP was calculated per treatment group. ATP concentration assay was performed ten times independently with or without serum. 


\section{Survival curve}

One hundred larvae were exposed to $100^{\circ} \mathrm{C}$ heat block for 30 second intervals from 0 to 120 seconds. Survivability was determined as a percent of live, motile larvae to the total number of larvae in the sample. Outstretched, non-motile larvae were considered dead. Corresponding ATP concentrations were measured for each sample. Lethal dose $50\left(\mathrm{LD}_{50}\right)$ was calculated as the concentration of ATP when $50 \%$ of the larvae present were killed by heat treatment. The $\mathrm{LD}_{50}$ was used as a threshold to evaluate the condition of experimental treatment groups.

\section{Preliminary infection of lambs using PBMC-exposed larvae}

Three naive SUF lambs were randomly assigned to receive one of three larval treatments. Infective $\mathrm{L}_{3}$ were obtained through the collection of fresh feces from infected animals and cultured as described previously. Larvae were exposed to STC-derived PBMC, SUF-derived PBMC or left untreated and incubated at $37^{\circ} \mathrm{C}$ for 18 hours. Cells were lysed with water and rinsed before re-suspending larvae in PBS. Each lambs was administered 5,000 PBMC-exposed H. contortus $\mathrm{L}_{3}$. Fecal samples were obtained weekly for 8 weeks to determine FEC, and blood was collected to measure PCV.

\section{Statistical analysis}

Data were analyzed using SigmaPlot software (Systat Software). Main effect of breed was compared by one-way ANOVA using Holm-Sidak method to determine differences. Pairwise comparisons were analyzed using Fisher LSD method. Survival of larvae was determined using Kaplan-Meier Survival Analysis log-rank test. Significance was accepted at $P$ $<0.05$. 


\section{Chapter 3: Results}

\section{Determination of ATP value associated to $\mathrm{LD}_{50}$}

To establish a $\mathrm{LD}_{50}$, samples of $100 \mathrm{~L}_{3}$ were heated to $100^{\circ} \mathrm{C}$ for 0,30 , 60 or 120 seconds. Following treatment, larvae were enumerated and evaluated as motile (live) or nonmotile and outstretched (dead). At 2 minutes, $100 \%$ of larvae exposed to heat treatment were killed, and ATP was reduced to $0.02 \mu \mathrm{M}$ (Figure 1) as compared to untreated, live control larvae with $0.2 \mu \mathrm{M}$ ATP. From this data, an $\mathrm{LD}_{50}$ of $0.13 \mu \mathrm{M}$ ATP was established, allowing for the numerical characterization of larvae in subsequent experiments. Furthermore, heat-treated larvae had reduced survival as compared to control larvae $(P<0.001)$ [Figure 1].

\section{Effect of breed and immune status on larval ATP after exposure to PBMC}

To determine effect of PBMC on larval damage, $\mathrm{L}_{3}$ were isolated following co-culture with cells, and metabolic activity was measured as concentration of larval ATP. It was hypothesized that PBMC derived from primed parasite-resistant STC sheep would significantly reduce larval ATP when compared to naive STC and either primed SUF or naïve SUF groups. However, no differences were observed between immune statuses. Larvae exposed to SUFderived PBMC had $0.16 \mu \mathrm{M}$ ATP, and larvae exposed to STC-derived PBMC had $0.12 \mu \mathrm{M}$ ATP, which was lower than the establish $\mathrm{LD}_{50}$ threshold (0.13 $\mu \mathrm{M}$ ATP) [Figure 2a]. Overall, concentration of ATP was significantly lower than live $(0.267 \mu \mathrm{M}$ ATP $)$ in both groups treated with PBMC regardless of breed $(P<0.001)$ and were also greater than heat-treated larvae $(0.03$ $\mu \mathrm{M}$ ATP) $(\mathrm{P}<0.001)$. Table 1 contains individual larval ATP values for each of 10 independent replications.

Additionally, ATP concentrations were analyzed as percent reduction of ATP from live control larvae. Reduction was calculated as experimental ATP subtracted from live ATP, 
divided by live larval ATP concentration value. From this analysis, STC-derived PBMC reduced larval ATP concentration by 54\% (Figure 2b). Reduction in ATP in larvae exposed to SUFderived PBMC was 39\% from live control larvae (Figure 2b). Heat-treated larval ATP was reduced by $88 \%$ from live untreated controls (Figure $2 \mathrm{~b}$ ).

\section{Effect of autologous serum on larval ATP following exposure to PBMC}

Autologous serum was added to PBMC-larval culture to determine the effect of serum on enhanced reduction of larval ATP. It was hypothesized that adding serum to culture should enhance PBMC responsiveness to larvae, and STC-derived PBMC with serum should reduce larval ATP to a greater extent than SUF-derived PBMC with serum on larval ATP. Adherence of PBMC to larvae was apparent immediately following the addition of autologous serum (serum from the same breed and immune status) [Figure 3a]. After 18 hours, a greater abundance of PBMC-derived from STC sheep adhered to larvae compared with PBMC-derived from SUF sheep (Figure 3b). In both treatment groups, large groupings of larvae were present and the majority of larvae were bound together (Figure 3a-b).

Larvae cultured with STC-derived PBMC (0.11 $\mu \mathrm{M}$ ATP) and serum had significantly reduced ATP concentration from live control $(0.22 \mu \mathrm{M}$ ATP $)(P<0.001)$ [Figure 3c], and concentration of ATP was reduced by 53\% (Figure 3d). However, STC-derived PBMC did not reduce ATP to the extent of heat-treated larvae (83\%), and ATP was greater than dead controls $(0.03 \mu \mathrm{M}$ ATP $)(P<0.001)$. Adding serum did not enhance SUF-derived PBMC mediated reduction of larvae ATP $(0.23 \mu \mathrm{M}$ ATP $)$, and ATP concentration was not significantly different from live control larvae $(0.22 \mu \mathrm{M}$ ATP) (Figure 3c-d). Furthermore, SUF-derived PBMC with serum were unable to reduce larval ATP as analyzed using percent-reduction from live (-0.8 \%), 
indicating increased ATP (Figure 3d). Table 2 contains individual larval ATP values for each of 10 independent replications.

\section{Larval infectivity following exposure to PBMC from different breeds}

To investigate infectivity, $\mathrm{L}_{3}$ were cultured with PBMC from STC, SUF, or untreated.

Following culture, 5,000 $\mathrm{L}_{3}$ were isolated from each group and administered to susceptible, naïve SUF lambs. Due to the preliminary nature of this experiment, only one lamb per treatment group was available. By week 5 following infection, differences were observed in FEC from lambs. Administration of STC-exposed larvae resulted in an FEC of 1700 epg, whereas the lamb administered SUF-exposed larvae had an FEC of 3,750 epg, and control FEC at 14,100 epg (Figure 4a). At week 8 the experiment was terminated. The lamb receiving STC-exposed larvae had an FEC of 1,150 epg, SUF-exposed larvae with an FEC of 3,950 epg, and FEC at 11,750 epg in the control lamb (Figure 4a). Averaging FEC over all time points, STC-exposed larvae were not significantly different from SUF-exposed larvae however, both groups were significantly lower than control (Figure 4b). 


\section{Chapter 4: Discussion}

Motility based classification is an inefficient method of measuring larval viability. A study have examining eosinophil accumulation around $H$. contortus $\mathrm{L}_{3}$ in vitro demonstrated immobilized $L_{3}$, and larvae remained immobile for up to three days (Rainbird et al., 1998) and, therefore, considered larvae to be dead. This was further supported using transmission electron microscopy (TEM), which showed direct adherence and degranulation of eosinophils on $\mathrm{L}_{3}$ (Rainbird et al., 1998). Similarly, larval motility was reduced following incubation with PBMC derived from either primed or naïve STC or primed SUF sheep, but not naïve SUF PBMC (Holt et al., 2015). Microscopic analysis demonstrated greater cellular adherence to larvae, which inhibited both functions of larval motility larval velocity and acceleration, after co-culture (Holt et al., 2015). However, these studies relied on observational reduction in motility, classifying larvae as non-motile or motile only. What these studies fail to address is measurable mortality, nor do they address infectivity of larvae as their ability to establish and reproduce in susceptible sheep.

Measuring larval metabolic activity using ATP provides a method to asses larval morbidity, because energy is essential for larval development into blood feeding adult worms inhabiting the mucosa. Larvae must sustain motility to resist blood flow at site of infection, as well as counteract peristaltic contractions, which can negatively impact establishment (Ishiwata and Watanbe, 2007). Altered metabolism can also reflect direct damage to larvae, as larvae must expend ATP to repair damaged cuticular structures. In a study using Nippostrongylus adult worms, damage was measured as the appearance of large vacuoles in gut cells and corresponding reduction in worm activity in vitro (Ogilvie and Hockley, 1968). Ishiwata and Watanbe (2007) determined that reduced ATP correlated with a reduction in motility. As a result of immune- 
mediated suppression of $N$. brasiliensis, adult worms in the mucosa had suppressed energy metabolism, which was due to inhibition of feeding activity (Ishiwata and Watanbe, 2007). In the current study, ATP was used to determine larval death and to establish a death threshold, which could be used to characterize larval death following exposure to PBMC.

In contrast to observed differences in larval motility, when $\mathrm{L}_{3}$ were cultured with PBMC immune status did not have an effect on larval ATP. In other studies, despite clear differences in FEC and PCV, only minor differences in immune responsiveness have been observed between lymphoproliferation using PBMCs from Dorset lambs compared to STC lambs (Gamble and Zajac, 1992). Both breeds had increased levels of parasite-specific antibody and mucus involved in mediating larval paralysis (Gamble and Zajac, 1992), suggesting difference in immune response must rely on different mechanisms.

A Th2 response involves many aspects of host immunity, including innate and adaptive cells, as well as antibody production in order to clear $H$. contortus. While St. Croix develop a strong Th2 response and susceptible breeds do not (Alba-Hurtado and Muñoz-Guzmán, 2013), an in vitro system comprised only of lymphocytes and monocytes may be enough to kill $H$. contortus larvae in the absence of other immune components. Peripheral blood mononuclear cells contain potent adaptor $\mathrm{T}$ cells, conferring specificity and memory, as well as mononuclear cells, which act to bridge adaptive and innate responses through antigen presentation. While larvae are too large for phagocytosis by macrophages, these cells may be considered a key player in clearance of helminth infection. Alternatively activated macrophages secrete IL-4 and IL-10, along with chemotactic factors, and express complement receptors, which contribute to cellular recruitment to the site of infection, Th2 differentiation and ultimately parasite clearance. Macrophages were observed in culture to permanently adhere to $T$. spiralis larvae while retaining 
cellular integrity (Mackenzie et al., 1980) when compared to neutrophils, mast cells and eosinophils, supporting a direct role of macrophages in parasite clearance. Cellular adherence contributed to greater reduction in mobility and increased damage to larvae. Hence, in the absence of humoral immunity and complement factors, a cellular response alone is capable of killing $H$. contortus larvae in vitro, despite observed differences in motility between breeds and immune status. Cell-mediated immunity alone may provide one explanation for observed lack of differences between larvae exposed to STC or SUF-derived PBMC.

Another possible explanation contributing to the lack of differences in larval ATP when exposed to PBMC alone may be attributed to the age or relativity maturity of sheep. Immunity varies between and within breeds and depends on multiple factors such as antigenic stimulus, nutrition, size and age of the animals (Greer and Hamie, 2016). Relative maturity compares mean live weight when an animal has developed immunity and mature weight to determine a sheep's metabolic age rather than chronological age. Resistance observed in STC lambs following a priming infection were influenced by both age and prior exposure to parasites (Gamble and Zajac, 1992). Lambs in this study were all infected at the same chronologic age and given the same antigenic exposure; however, SUF lambs are generally larger than STC lambs, which may have contributed to development of relative maturity in SUF and earlier development of responsiveness to $H$. contortus. Furthermore, regardless of breed, susceptible breeds will establish some resistance with maturity and antigenic exposure to $H$. contortus (Gamble and Zajac, 1992). However, this cannot fully account for the lack of differences or for measured differences in larval ATP when autologous serum was added to culture.

Larval ATP reduction was enhanced upon addition of serum to STC-derived PBMC. Parasite-resistant sheep develop a stronger acquired immune response and have increased 
circulating antibody (MacKinnon et al., 2010; Bowdridge et al., 2013). St. Croix hair ewes generated greater antigen-specific IgA in response to $H$. contortus infection (Bowdridge et al., 2013). In vitro studies involving multiple species of helminth larvae and innate immune cells demonstrated that larvae coated with antibody enhanced leucocyte adherence to the larval cuticle (Soulsby, 1963), and antibody was able to effectively immobilize $H$. polygyrus larvae independent of CD11b, the key complement receptor mediating macrophage attachment to larvae (Esser-von Bieren et al., 2015). Mackenzie et al. (1980) demonstrated that antibodies directed against surface antigens were highly specific towards different $N$. brasiliensis life stages and altered worm survival in vitro. Increased circulating antibody corresponded to increased cellular attachment, and the presence of antibody influences the length of time cells remained attached to larvae (Mackenzie et al., 1981), thereby influencing cellular effects against larvae. Macrophages work in collaboration with eosinophils, killing $T$. spiralis larvae more rapidly when serum was added in culture (Mackenzie et al., 1980). Together these studies suggest a role of antibody contributing to a greater and more potent cellular response that may account for observed differences in larval ATP in the current study.

While microscopy revealed that whole serum from either breed rapidly enhanced cellular adherence, addition of autologous serum to SUF-derived PBMC culture eliminated cell-mediated killing. Because cellular adherence was not inhibited, antibody derived from either breed can recognize and bind to larvae, yet differences may be present in serum components. Studies suggest a role for complement in larvicidal activity in helminth mediation. When whole serum was heat treated to eliminate complement, eosinophil adhesion and killing was abrogated, whereas depletion of IgG or IgM had no effect (Shin et al., 2001). One explanation of the mechanism of action is that complement activation has been shown to increase adhesiveness of 
cells in vitro (O'Flaherty et al., 1978). It is well understood that helminths have developed strategies to avoid complement recognition, which is critical in early stages of infection. Loss of complement activation and leukocyte adherence was demonstrated to be dependent on $N$. brasiliensis larval stage (Giacomin et al., 2005), where some parasitic larvae shed their cuticle and acquire host proteins, including complement regulatory protein decay accelerating factor (Santoro et al., 1979). Observation of St. Croix sheep immune response further corroborates these observations in $H$. contortus infection. Hair type sheep respond early to $H$. contortus infection, which promotes early development of an acquired immune response, thereby limiting establishment of adult worms (Bowdridge et al, 2015).

From a parasitological view, parasites able to evade components of complement and subvert complement attack have an advantage, permitting establishment (Goto and Sanchez, 2013). Secretion of calreticulin binding protein by $H$. contortus inhibits the classical complement pathway, which can prevent leukocyte influx, thereby enhancing parasite survival (Suchitra et al., 2008; Sahoo et al., 2013). In addition to evasion of the classical complement pathway, H. contortus secretes a complement-C3-binding protein (C3BP) in their excretorysecretory products, which inhibit complement activity (Sahoo et al., 2013). As STC have been documented to develop an early response and therefore early recognition, differences between parasite susceptible and parasite resistant breeds could also be linked to differences in complement proteins. When plasma concentration of complement proteins $\mathrm{C} 3$ and $\mathrm{C} 4$ were measured in a population of Suffolk sheep compared to merino sheep, it was found that C3 concentrations were elevated in merino sheep, where C4 was significantly reduced (Groth et al., 1987). Additionally, when analyzed using immunoprecipitation, differences were observed in protein size, suggesting multiple loci and polymorphisms between sheep (Groth et al., 1987) 
which can be attributed to observed differences in circulating complement. Taken together, deficiencies in SUF complement activation or polymorphisms in complement proteins may account for observed differences in larval ATP when $\mathrm{L}_{3}$ are cultured with SUF-derived PBMC and serum. However complement differences between breeds have yet to be fully established.

Preliminary experimental data demonstrated reduced FEC in susceptible SUF lambs given an oral inoculation of PBMC-exposed $H$. contortus $\mathrm{L}_{3}$. In a similar study, Blackbelly sheep had reduced FEC and fewer established adult worms when sheep received an intraabomasal transfer of $\mathrm{L}_{3}$ cultured with eosinophils (Terefe et al., 2007a), further substantiating the role of innate cells on $H$. contortus $\mathrm{L}_{3}$ viability, both in vitro and in vivo. While this study's aim was to measure infectivity of larvae following immune cell exposure, it fails to provide biologic relevance. In contrast to an intra-abomasal inoculation, an oral dose of $H$. contortus mimics a typical infection and immune response, as larvae must migrate to the abomasum. Furthermore, Blackbelly sheep are considered parasite resistant, which may have contributed to a reduction in FEC. Nevertheless, reduced larval motility and immune-mediated damage, reflected in reduced ATP, manifest as reduced adult worm size and fecundity (Chandler, 1936), which may account for reduced FEC. Immune-mediated reduction in energy may then lead to expulsion of $\mathrm{L}_{3}$ from sheep. Alternatively, cell-mediated damage to larvae could also promote inhibition of larval feeding activity, thereby suppressing energy metabolism of adult worms (Ishiwate and Watanbe, 2007).

Our current study was able to demonstrate that differences in larval viability could be measured using ATP concentration following exposure to PBMC in vitro, establishing a role of mononuclear cell-induced larval death. These data were supported in vivo, suggesting that PBMC are able to directly damage and kill $H$. contortus larvae as demonstrated through reduced 
FEC following infection of susceptible lambs. While a cell-mediated response alone may be enough to kill $\mathrm{L}_{3}$, differences between parasite resistant and parasite susceptible breed innate and humoral responses may be a potential target in developing future therapeutics against $H$. contorus in ruminants. 


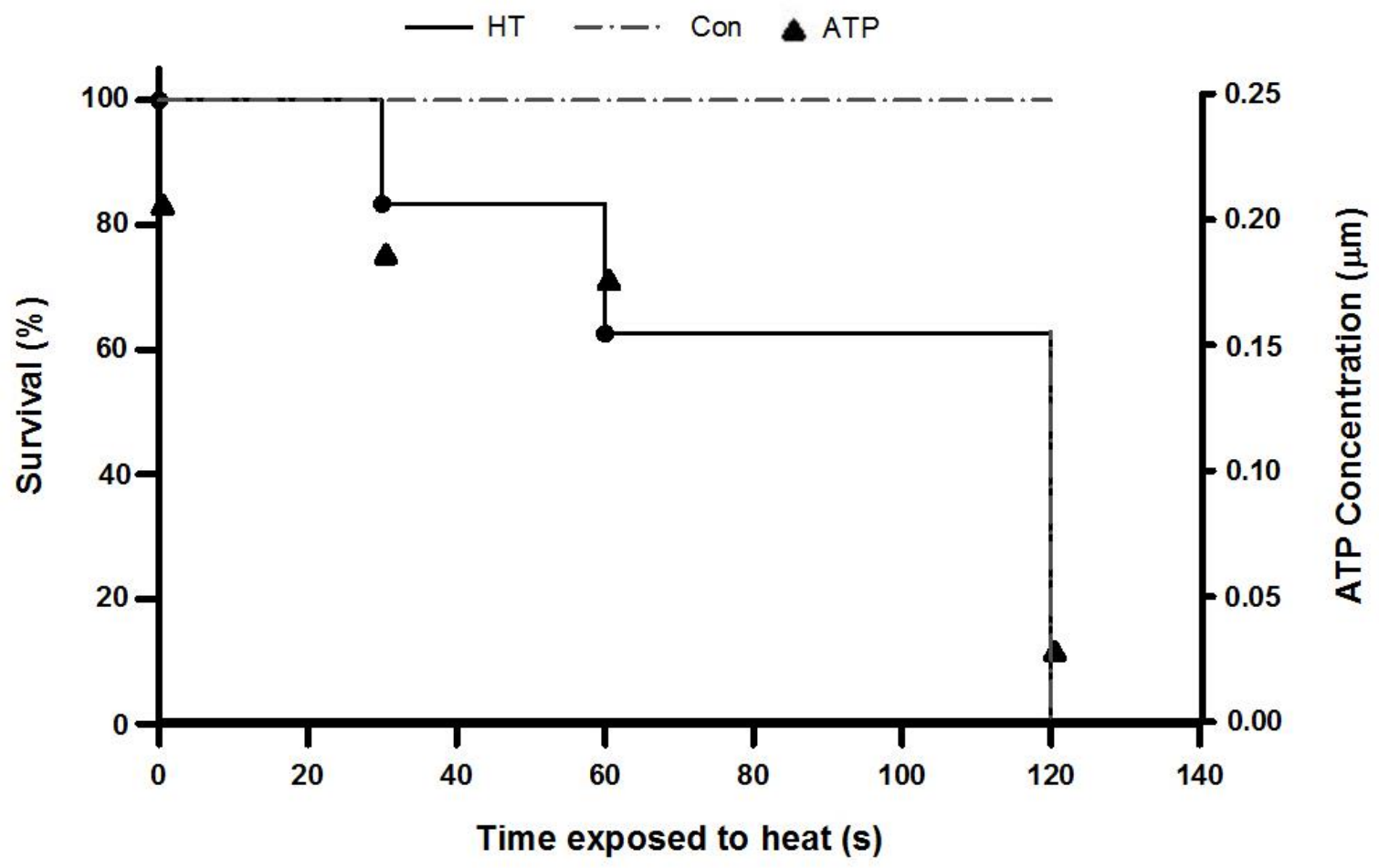

Figure 1: Larval survivability following heat treatment

Larval survivability determined as a percent of live, motile larvae to the number of outstretched, non-motile larvae after exposure to $100^{\circ} \mathrm{C}$. $\mathrm{LD}_{50}$ was determined as the ATP concentration when half of larvae present were alive $\left(\mathrm{LD}_{50}=0.13 \mu \mathrm{M}\right.$ ATP $)$. Data represents the mean of three independent experiments; 100 larvae were used per treatment. $P<0.001$ 

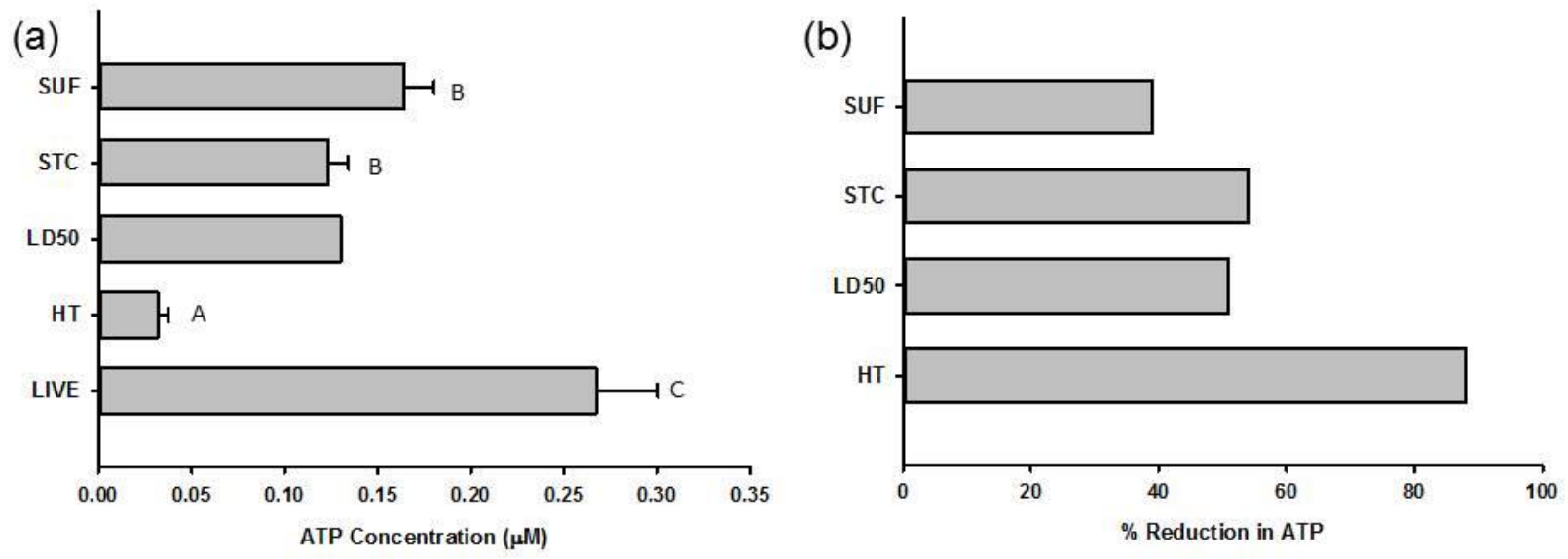

Figure 2: Larval ATP concentration after exposure to PBMC from SUF or STC sheep.

(a) ATP concentration of $\mathrm{L}_{3}$ exposed to SUF, STC PBMC or heat treated $\mathrm{L}_{3}$ positive control (dead) and untreated negative control (live). (b) Reduction of experimental ATP concentration from live ATP concentration. Data is representative of 10 individual experiments. Error bars represent SEM. Different letters indicate significant difference; $P<0.001$ 

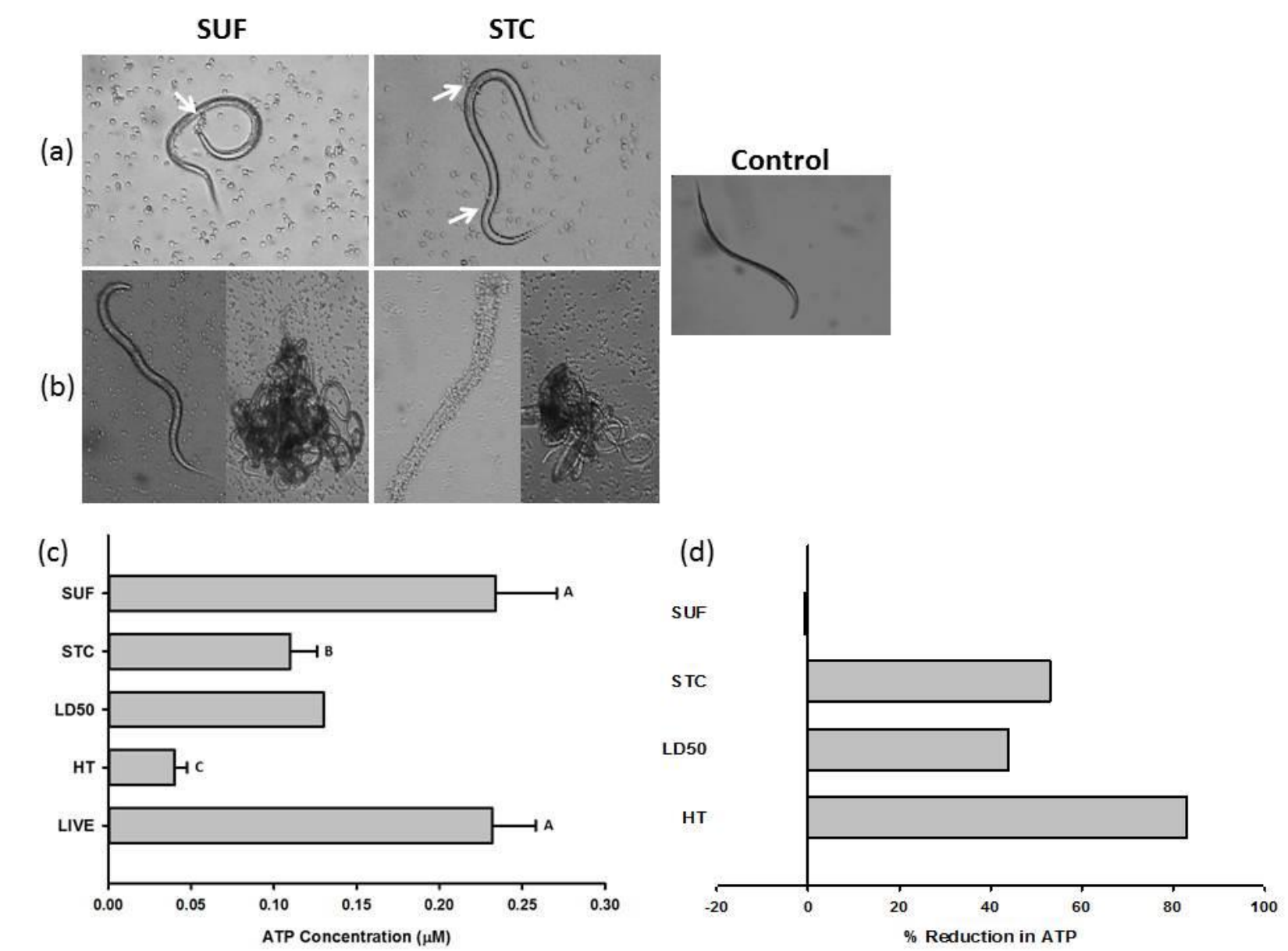

Figure 3: Larval ATP following culture with PBMC and autologous serum.

Microscopy at 10x magnification (a) at time 0 and (b) $18 \mathrm{hr}$ after addition of serum. Magnification at 10x (left panel) and 4x (right panel). (c) Larval ATP concentration following incubation with STC or SUF-derived PBMC and autologous serum. Heat-treated positive control (HT) and untreated (live) negative control ATP concentration (d) Reduction of experimental ATP from live ATP concentration. Data are representative of the mean of 10 replicates. Error bars represent SEM. Different letters indicate significant difference; $P<0.001$ 

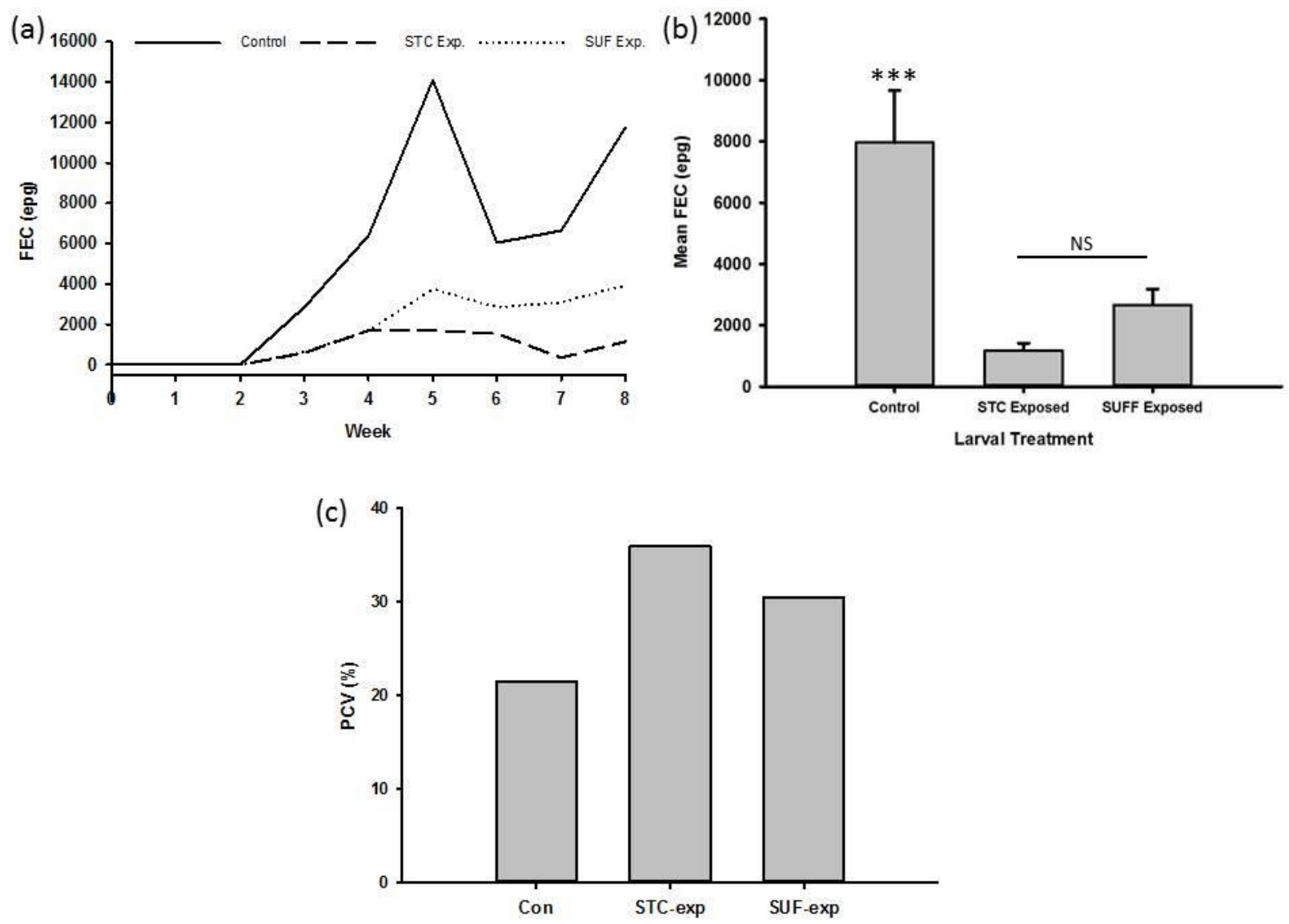

Figure 4: Infectivity of PBMC-exposed larvae

(a) SUF lamb FEC measured over 8 weeks for sheep $(\mathrm{n}=1)$ administered 5,000 $\mathrm{L}_{3}$ per treatment group. (b) Mean FEC over 8 week period per treatment group. (c) PCV between weeks 5 and 8 of experiment. Error bars represent SEM. $* * * P<0.001$. 
Table 1: Larval ATP concentration after exposure to PBMC

\begin{tabular}{|c|c|c|c|c|c|c|c|c|c|c|c|c|}
\hline \multirow[b]{2}{*}{$\begin{array}{l}\text { PBMC } \\
\text { Source }\end{array}$} & \multicolumn{10}{|c|}{ Replication } & \multirow[b]{2}{*}{ Mean } & \multirow[b]{2}{*}{ SE } \\
\hline & 1 & 2 & 3 & 4 & 5 & 6 & 7 & 8 & 9 & 10 & & \\
\hline Naïve SUF & 0.158 & 0.090 & 0.158 & 0.232 & 0.274 & 0.151 & 0.105 & 0.120 & 0.092 & 0.221 & 0.160 & 0.021 \\
\hline Naïve STC & 0.098 & 0.077 & 0.098 & 0.186 & 0.202 & 0.065 & 0.181 & 0.121 & 0.102 & 0.150 & 0.128 & 0.017 \\
\hline Primed SUF & 0.121 & 0.059 & 0.120 & 0.064 & 0.293 & 0.264 & 0.179 & 0.171 & 0.130 & 0.277 & 0.168 & 0.027 \\
\hline Primed STC & 0.132 & 0.057 & 0.130 & 0.065 & 0.223 & 0.113 & 0.117 & 0.082 & 0.110 & 0.160 & 0.119 & 0.016 \\
\hline Live & 0.419 & 0.107 & 0.419 & 0.287 & 0.367 & 0.240 & 0.224 & 0.217 & 0.167 & 0.225 & 0.267 & 0.037 \\
\hline Dead & 0.031 & 0.017 & 0.030 & 0.011 & 0.046 & 0.011 & 0.051 & 0.036 & 0.022 & 0.063 & 0.032 & 0.005 \\
\hline
\end{tabular}


Table 2: Larval ATP concentration following incubation with PBMC and autologous serum

\begin{tabular}{|c|c|c|c|c|c|c|c|c|c|c|c|c|}
\hline \multirow[b]{2}{*}{$\begin{array}{l}\text { PBMC } \\
\text { Source }\end{array}$} & \multicolumn{10}{|c|}{ Replication } & \multirow[b]{2}{*}{ Mean } & \multirow[b]{2}{*}{ SE } \\
\hline & 1 & 2 & 3 & 4 & 5 & 6 & 7 & 8 & 9 & 10 & & \\
\hline Naïve SUF & 0.16 & 0.26 & 0.12 & 0.20 & 0.13 & 0.20 & 0.05 & 0.47 & 0.08 & 0.34 & 0.20 & 0.02 \\
\hline Naïve STC & 0.01 & 0.23 & 0.11 & 0.18 & 0.11 & 0.11 & 0.09 & 0.09 & 0.05 & 0.05 & 0.10 & 0.03 \\
\hline Primed SUF & 0.08 & 0.33 & 0.32 & 0.07 & 0.03 & 0.08 & 0.22 & 0.57 & 0.48 & 0.46 & 0.27 & 0.06 \\
\hline Primed STC & 0.03 & 0.11 & 0.16 & 0.12 & 0.03 & 0.08 & 0.33 & 0.11 & 0.11 & 0.11 & 0.12 & 0.02 \\
\hline Live & 0.11 & 0.37 & 0.24 & 0.22 & 0.22 & 0.17 & 0.23 & 0.33 & 0.11 & 0.21 & 0.22 & 0.04 \\
\hline Dead & 0.02 & 0.05 & 0.01 & 0.05 & 0.04 & 0.02 & 0.06 & 0.04 & 0.09 & 0.03 & 0.04 & 0.01 \\
\hline
\end{tabular}




\section{Literature Cited:}

Alba-Hurtado, F. and M.A. Munoz-Guzman. 2013. Immune Responses Associated with Resistance to haemonchosis in sheep. BioMed Res. Int. 2013: 162158

Allen J.E., T.E. Sutherland and D. Ruckerl. 2015. IL-17 and neutrophils: unexpected players in the type 2 immune response. Curr. Opin. Immunol. 34:99-106.

Anthony, R.M., J.F. Urban Jr, F.Alem, H.A. Hamed, C.T. Rozo, J. Boucher, N. Van Rooijen and W.C. Gause. 2006. Memory Th2 cells induce alternatively activated macrophages to mediate protection against nematode parasites. Nat. Med. 12(8):955-960.

Anthony, R.M., L.I. Rutitzky, J.F. Urban Jr, M.J. Stadecker and W.C. Gause. 2007. Protective immune mechanisms in helminth infection. Nat. Rev. Immunol. 7(12):975-987.

Balic, A., V.M. Bowles and E.N.T Meeusen. 2000. The immunobiology of gastrointestinal nematode infections in ruminants. Adv. Parasitol. 45:181-241.

Balic, A., V.M. Bowles, and E.N.T. Meeusen. 2000b. Cellular profiles in the abomasal mucosa and lymph node during primary infection with Haemonchus contortus in sheep. Vet. Immunol. Immunopathol. 75:109-120.

Bancroft, A.J., K.J. Else and R.K. Grencis. 1994. Low-level infection with Trichuris muris significantly affects the polarization of the CD4 response. Eur. Immunol. 24(12):3113-3118

Bass, D.A. and P. Zejda. 1979. Eosinophils versus neutrophils in host defense. J. Clin. Invest. 64:1415-1422.

Bonne-Annee, S., L.A. Kerepsei, J.A. Hess, A.E. O’Connell, J.B. Lok, T.J. Nolan and D. Abraham. 2013. Human and mouse macrophages collaborate with neutrophils to kill larval Strongyloides stercoralis. Infect. Immunol. 81(9):3346-3355.

Bowdridge, S.A., K. MacKinnon, J.C. McCann, A.M. Zajac, and D.R. Notter. 2013. Hair-type sheep generate an accelerated and longer-lived humoral immune response to Haemonchus contortus infection. Vet. Parasitol. 196:172-178.

Bowdridge, S.A., A.M. Zajac and D.R. Notter. 2015. St. Croix sheep produce a rapid and greater cellular immune response contributing to reduced establishment of Haemonchus contortus. Vet. Parasitol. 208: 204-210.

Brunei, L.R., E.A. Sabin, A.W. Cheever, M.A. Kopf and E.J. Pearce. 1999. Interleukin 5 (IL-5) is not required for expression of a Th2 response or host resistance mechanisms during murine Schistosomiasis mansoni but does play a role in development of IL-4 producing non-T, non-B cells. Infect. Immunol. 67:3014-3018. 
Clark, C.H., G.K. Kiesel and C.H. Goby. 1962. Measurements of blood loss caused by Haemonchus contortus infection in sheep. Am. J. Vet. Res. 23:977-980.

Chandler, A.C. 1936. Studies on the nature of immunity to intestinal helminthes. III. Renewal of growth and egg production in Nippostrongylus after transfer from immune to nonimmune rats. Amer. J. Hygiene. 23:46-54.

Chen, F., Z. Liu, W. Wu, C. Rozo, S. Bowdridge, A. Millman, N. Van Rooijen, J.F. Urban Jr, T.A. Wynn and W.C. Gause WC. 2012. An essential role for Th2-type responses in limiting acute tissue damage during experimental helminth infection. Nat. Med. 18(2):260267.

Chen, F., W. Wu, A. Millman, J.F. Craft, E. Chen, N. Patel, J.L. Boucher, J.F. Urban Jr, C.C. Kim and W.C. Gause. 2014. Neutrophils prime a long-lived effector macrophage phenotype that mediates accelerated helminth expulsion. Nat. Immunol. 15:938-946

Courtney, C.H., C.F. Parker, K.E. McClure and R.P. Herd. 1985. Resistance of exotic and domestic lambs to experimental infection with Haemonchus contortus. Int. J. Parasitol. 15(1):101-109.

Craig, N.M., H.R. Miller, W.D. Smith, and P.A. Knight. 2007. Cytokine expression in naïve and previously infected lambs after challenge with Teladorsagia circumcincta. Vet Immunol. Immunopathol. 120(1-2)47-54.

Douch, P.G.C., G.B.L. Harrison, L.L. Buchanan and K.S. Greer. 1983. In vitro bioassay of sheep gastrointestinal mucus for nematode paralyzing activity mediated by substances with some properties characteristic of SRS-A. Int. J. Parasitol. 13(2):207-2012.

Douch, P.G.C. and P.E. Morum. 1994. The effects of anthelmintics on ovine larval nematode parasite migration in vitro. Int. J. Parasitol. 24(3):321-326.

Elliot, D.C. 1981. The fate of infective Trichostrongylus colubriformis larvae in a resistant sheep. Wallaceville Animal Research Centre Annual Report, page 28.

Else, K.J.and F.D. Finkelman. 1998. Intestinal nematode parasites, cytokines and effector mechanisms. Int. J. Parasitol. 28:1145-1158.

Esser-von Bieren, J., B. Volpe, M. Kulagin, D.B. Sutherland, R. Guiet, A. Seitz, B.J. Marsland, J.S. Verbeek, and N.L. Harris. 2015. Antibody-mediated trapping of helminth larvae requires CD11b and Fcy Receptor I. J. Immunol. 194(3):1154-1163

Fallon, P.G., S.J. Ballantyne, N.E. Mangan, J.L. Barlow, A. Dasvarma, D.R. Hewett, A. McIlgorm, H.E. Jolin and A.N. McKenzie. 2006. Identification of an IL-25-dependent cell 
population that provides IL-4, IL-5 and IL-13 at the onset of helminth expulsion. J. Exp Med. 203(4):1105-1116.

Gamble, H.R. and A.M. Zajac. 1992. Resistance of St. Croix lambs to Haemonchus contortus in experimentally and naturally acquired infections. Vet. Parastiol. 41:211-225.

Gibbs, H.C. 1973. Hypobiosis and periparturient rise in sheep. Vet. Clin. N. Am: Food Anim. Pract. 2(2):345-353.

Gill, H.S., D.L. Watson and M.R. Brandon. 1993. Monoclonal antibody to CD4+ T cells abrogates genetic resistance to Haemonchus contortus in sheep. Immunol. 78:43-49.

Gill, H.S., K. Altmann, M.L. Cross, and A.J. Husband. 2000. Induction of T helper 1- and T helper 2-type immune responses during Haemonchus contortus infection in sheep. Immunol. 99(30):458-463.

Georgi, J.R. and J.H. Whitlock. 1967. Erythrocyte loss and restitution in ovine haemonchosis. Estimation of erythrocyte loss in lambs following natural exposure. Cornell Vet. 57(1):4353.

Giacomin, P.R., H. Wang, D.L. Gordon, M. Botto, and L.A. Dent. 2005. Loss of complement activation and leukocyte adherence as Nippostrongylus brasiliensis develops without the murine host. Inf. Immun. 73(11):7442-7449.

Goto, H. and M.C.A. Sanchez. 2013. Does the complement system work for or against the host during parasite infections? Int. Tren. Immun. 1(2):11-23.

Gratchev, A., J. Kzhyshokowska, J. Utikal and S. Goerdt. 2005. Interleukin-4 and dexamethasone counter-regulate extracellular matrix remodeling and phagocytosis in type2 macrophages. Scand. J. Immunol. 61:10-17.

Gray, G.D. 1995 Genetic variation in resistance to parasites. Page 43-52 in Breeding for Resistance to Infectious Diseases in Small Ruminants. GD Gray, RR Woolaston and BT Eaton. ACIAR, Canberra.

Greer, A.W. and J.C. Hamie. 2016. Relative maturity and the development of immunity to gastrointestinal nematodes in sheep: An overlooked paradigm? Parasit. Immunol. 38(5):263-272.

Groth, D.M., J.D. Wetherall, P.M. Outteridge, R.G. Windon, B. Richards, and I.R. Lee. 1987. Analysis of C3 and C4 in ovine plasma. Complement. 4(1):12-20.

Guo, L., Y. Huang, X. Chen, J. Hu-Li, J.F. Urban Jr and W.E. Paul. 2015. Innate immunological function of Th2 cell in vivo. Nat. Immunol. 16:1051-1059. 
Herndon, F.J. and S.G. Kayes. 1992. Depletion of eosinophils by anti-IL-5 monoclonal antibody treatment of mice infected with Trichinella spiralis does not alter parasite burden or immunologic resistance to reinfection. J. Immunol. 149(11):3642-3647.

Holt, R., E.A. Shepherd, A. Ammer and S.A. Bowdridge. 2015. Effects of peripheral blood mononuclear cells on Haemonchus contortus larval motility in vitro. Parasit. Immunol. 37:553-556.

Howell, S.B., J.M. Burke, J.E. Miller, T.H. Terrill, E. Valencia, M.J. Williams, L.H. Williamson, A.M. Zajac and R.M. Kaplan. 2008. Prevalence of anthelmintic resistance on sheep and goat farms in the southeastern United States. Am. J.Vet. Res. 233(12):1913-1919

Huntley, J.F., M. Patterson, A. MacKellar, F. Jackson, L.M. Stevenson and R.L. Coop. 1995. A comparison of the mast cell and eosinophil responses of sheep and goats to gastrointestinal nematode infections. Res.Vet. Sci. 58:5-10.

Ingham, A., A. Reverter, R. Windon, P. Hunt and M. Menzies. 2008. Gastrointestinal nematode challenge induces some conserved gene expression changes in the gut mucosa of genetically resistant sheep. Int. J. Parasitol. 38 (3-4):431-442.

Ishiwata K., and N. Watanabe. 2007. Nippostrongylus brasiliensis: reversibility of reducedenergy status associated with the course of expulsion from the small intestine in rats. Exp. Parasitol. 117(1):80-86.

Karanu, F.N., R.C. McGuire, W.C. Davis, T.E. Besser and D.P. Jasmer. 1997. CD+ T lymphocytes contribute to protective immunity induced in sheep and goats by Haemonchus contortus gut antigens. Parasit. Immunol. 19(10):435-445.

Kemp, J.M., N.A. Robinson, E.N.T. Meeusen, and D.M. Pidrafita. 2009. The relationship between the rapid rejection of Haemonchus contortus larvae with cells and mediators in abomasal tissues in immune sheep. Int. J. Parasitol. 39:1589-1594.

Kimambo, A.E. and J.C. MacRae. 1988. Measurement in vitro of a larval migration inhibitory factor in gastrointestinal mucus of sheep made resistant to the roundworm Trichostrongylus colubriformis. Vet. Parasitol. 28:213-222.

Kooyman, F.N., P.J. Van Kooten, J.F. Huntley, A. MaacKellar, A.W. Cornelissen and H.D. Schallig. 1997. Production of a monoclonal antibody specific for ovine immunoglobulin E and its applications to monitor serum IgE responses to Haemonchus contortus infection. Parasitol. 114(4):395-406.

Kreider, T., R.M. Anthony, J.F. Urban Jr and W.C. Gause. 2007. Alternatively activated macropahges in helminth infections. Cur. Opin. Immunol. 19:448-453 
Lacroux, C., T.H.C. Nguyen, O. Andreoletti, F. Prevot, C. Grisez, J.P. Bergeaud, L. Gruner, J.C. Brunel, D. Francois, P. Dorchies and P. Jaquiet. 2006. Haemonchus contortus (Nematode: Trichostrongylidae) infection in lambs elicits an unequivocal Th2 immune response. Vet. Res. 37:607-622.

La Flamme, A.C., M. Kharkrang, S. Stone, S. Mirmoeini, D. Chuluundorj and R. Kyle. 2012. Type II-activated murine macrophages produce IL-14. PLoS ONE 7(10):e46989.doi:10.1371/journal.pone.0046898.

Laurenson, Y.C., I. Kyriazakis, and S.C. Bishop. 2012. In silico exploration of the impact o pasture larvae contamination and anthelmintic treatment on genetic parameter estimates for parasites resistance in grazing sheep. J. Anim. Sci. 90(7):2167-80.

Liu, Q., T. Kreider, S. Bowdridge, Z. Liu, Y. Song, A.G. Gaydo, J.F. Urban Jr and W.C. Gause. 2010. B cells have distinct roles in host protection against different nematode parasites. J. Immunol. 184(9):5213-5223.

MacKinnon, K.M., J.R. Burton, A.M. Zajac and D.R. Notter. 2009. Microarray analysis reveals difference in gene expression profiles of hair and wool sheep infected with Haemonchus contortus. Vet. Immunol. and Immunopath. 130(3-4):210-220.

MacKinnon, K.M., A.M. Zajac, F.N.J. Kooyman and D.R. Notter. 2010. Differences in immune parameters are associated with resistance to Haemonchus contortus in Caribbean hair sheep. Parasit. Immunol. 32:484-493

Mackenzie C.D., M. Jungery, P.M. Taylor and B.M. Ogilvie. 1980. Activation of complement, the induction of antibodies to the surface of nematodes and the effects of these factors and cells on worm survival in vitro. Eur. J Immunol. 10:594-601.

Mackenzie, C.D., M. Jungery, P.M. Taylor, and B.M. Ogilvie. 1981. The in-vitro interaction of eosinophils, neutrophils, macrophages and mast cells with nematode surfaces in the presence of complement or antibodies. Path. 133:161-175.

Madden, K.B., J.F. Urban Jr, H.J. Ziltener, J.W. Schrader, F.D. Finkelman and I.M. Katona. 1991. Antibodies to IL-3 and IL-4 suppress helminth-induced intestinal mastocytosis. J. Immunol. 147(4):1387-1391.

Martin, P.J. and L.F. Le Jambre. 1979. Larval paralysis as an in vitro assay of levamisole and morantel tartrate resistance in Ostertagia. Vet. Sci. Com. 3:159-164.

Martin, P. and S.J. Leibovich. 2005. Inflammatory cells during wound repair: the good, the bad and the ugly. Tren. Cell Biol. 15(11):599-607.

Meeusen, E.N.T. and A. Balic. 2000. Do eosinophils have a role in the killing of helminth parasites? Parasitol. Today. 16(3):95-101. 
Meeusen, E.N.T., A. Balic and V. Bowles. 2005. Cells, cytokines and other molecules associated with rejection of gastrointestinal nematode parasites. Vet. Immunol. Immunopath. 108:121125.

Miller, H.R.P., F. Jackson, G. Newlands and W.T. Appleyard. 1983. Immune exclusion, a mechanism of protection against the ovine nematode Haemonchus contortus. Res. Vet. Sci. 35:357-363.

Miller, H.R.P. 1984. The protective mucosal response against gastrointestinal nematodes in ruminants and laboratory animals. Vet. Immunol. Immunopath. 6:167-259.

Mornex, J.F., C. Leroux, T. Greeland and D. Ecochard. 1994. From granuloma to fibrosis in interstitial lung diseases: molecular and cellular interactions. Eur. Respir. J. 7(4):779-785.

Neill, D.R., S.H. Wong, A. Bellosi, R.J. Flynn, M. Daly, M. Langford, C. Bucks, C.M. Kane, P.G. Fallon, R. Pannel, H.E. Jolin and A.N.J. McKenzie. 2010. Nuocytes represent a new innate effector leukocyte that mediates type-2 immunity. Nat. 464(7293):1367-1370.

Notter, D.R., S.A. Andrew and A.M. Zajac. 2003. Responses of hair and wool sheep to a single fixed dose of infective larvae of Haemonchus contortus. Sm. Rum. Res. 47:221-225.

O’Flaherty, J.T., P.R. Craddock, and H.S. Jacob. 1978. Effects of intravascular complement activation on granulocyte adhesiveness and distribution. Blood. 51:731.

O'Garra, A. and K. Murphy. 1994. Role of cytokines in determining T-lymphocyte function. Curr. Opin. Immunol. 158:1085-1094.

Ogilvie, B.M. and D.J. Hockely. 1968. Effects of immunity on Nippostrongylus brasiliensis adult worms: reversible and irreversible changes in infectivity, reproduction and morphology. J. Parasitol. 54:1073-1084.

Oliphant, C.J., Y.Y. Hwang, J.A. Walker, M. Salimi, S.H. Wong, J.M Brewer, A. Englezakis, J.L. Barlow, E. Hams, S.T. Scanlon, G.S. Ogg and P.G. Fallon. 2014. MHCII-Mediated Dialog between Group 2 Innate Lymphoid Cells and CD4+ T Cells Potentiates Type 2 Immunity and Promotes Parasitic Helminth Expulsion. Immunity. 41:283-295.

Ortolani, E.L., M.L. do Rego Leal, A.H.H. Minervino, A.R. Aires, R.L. Coop, F. Jackson and N.F. Suttle. 2013. Effects of parasitism on cellular immune response in sheep experimentally infected with Haemonchus contortus. Vet. Parasitol. 196:230-234.

Patel, N., T. Kreider, J.F. Urban Jr, and W.C. Gause. 2009. Characterization of effector mechanisms at the host:parasite interface during the immune response to tissue-dwelling intestinal nematode parasites. Int. J. Parasitol. 39:13-21. 
Peña, M.T., J.E. Miller and D.W. Horohov. 2006. Effect of CD4+ T lymphocyte depletion on resistance of Gulf Coast Native lambs to Haemonchus contortus infection. Vet. Parasitol. 138:240-246.

Prussin, C. and D.D. Metcalfe. IgE, mast cells, basophils and esoinophils. 2003. J. Aller. Clin. Immunol. 111:S486-S494.

Rabel, B., R. McGregor and P.G.C. Couch. 1994. Improved bioassay for estimation of inhibitory effects of ovine gastrointestinal mucus and anthelmintics on nematode larval migration. Int. J. Parasitol. 24(5):671-676.

Rainbird, M.A., D. Macmillan and E.N. Meeusen. 1998. Eosinophil-mediated killing of Haemonchus contortus larvae: effect of eosinophil activation and role of antibody, comp lement and interleukin-5. Parasit. Immunol. 20:93-103.

Roberts, L.S. and J. Janovy. 2005. Foundations in parasitology. $7^{\text {th }}$ ed. McGraw Hill, New York, NY.p. 426

Robinson N, Piedrafita D, Snibson K, Harrison P, and Meeusen EN. 2010. Immune cell kinetics in the ovine abomasal mucosa following hyperimmunization and challenge with Haemonchus contortus. Vet. Res. 41(4):37.

Romagnani, S. 1991. Type $1 \mathrm{~T}$ helper and type $2 \mathrm{~T}$ helper cells: functions, regulation and role in protection and disease. Int. J. Clin. Lab. Res. 21(2):152-158.

Sahoo, S., S. Murugavel., I.K. Devi, G.V. Vedamurthy, S.C. Gupta, B.P. Singh and P. Joshi. 2013. Glyceraldehyde-3-phosphate dehydrogenase of the parasitic nematode Haemonchus contortus binds to complement $\mathrm{C} 3$ and inhibits its activity. Parasit. Immunol. 35:457-467.

Santoro, F., P.J. Lachmann, A. Capron, and M. Capron. 1979. Activation of complement by Schistosoma mansoni schistosomula: killing of parasites by the alternative pathway and requirement of IgG for classical pathway activation. J. Immunol. 123:1551-1557.

Schallig, H., M. van Leeuwen, W. Bernadina, and W. Hendrikx. 1994. Serum antibody responses of Texel sheep experimentally infected with Haemonchus contortus. Res. Vet. Sci. 57:6368. Schallig, H.D.F.H., M.A.W. Van Leeuwen and A.W.C.A. Cornelisen. 1997a. Protective immunity induced by vaccination with two Haemonchus contortus excretory secretory proteins in sheep. Parasit. Immunol. 19:447-453.

Schallig, H. 2000. Immunological responses of sheep to Haemonchus contortus. Parasitol. 120 Suppl: 72. 
Shakya, K.P., J.E. Millerand D.W. Horohov. 2009. A Th2 type of immune response is associated with increased resistance to Haemonchus contortus in naturally infect Gulf Coast Native lambs. Vet. Parasitol. 163:57-66.

Shin, E.H., Y. Osada, H. Sagara, K. Takatsu and S. Kojima. 2001. Involvement of complement and fibronectin in eosinophil-mediated damage to Nippostrongylus brasiliensis larvae. Parasit. Immunol. 23:27-37.

Soulsby, E. J. L. 1963. The nature and origin of the functional antigens in helminth infections. Ann. N.Y. Acad. Sci. 113:492.

Suchitra, S. K.A. Anbu, D.K. Rathore, M. Mahawar, B.P. Singh and P. Joshi. 2008. Haemonchus contortus calrecticulin binds to C-reactive protein of its host, a novel survival strategy of the parasite. Parasit. Immunol. 30(607):371-374.

Terefe, G., C. Lacroux, O. Andreoletti, C. Grisez, F. Prevot, J.P. Bergeaud, J. Penicaud, V. Rouillon, L. Gruner, J.C. Brunel, D. Francois, J. Bouix, P. Dorchies and P. Jacquiet. 2007. Immune response to Haemonchus contortus infection in susceptible (INRA 401) and resistant (Barbados Black Belly) breeds of lambs. Parasit. Immunol. 29:415-424.

Terefe G., C. Grisez, F. Prevot, J.P. Bergeaud, P. Dorchies, J.C. Brunel, D. Grancois, I. Fourquaux, and P. Jacquiet. 2007a. In vitro pre-exposure of Haemonchus contortus L3 to blood eosinophils reduces their establishment potential in sheep. Vet. Res. 38(4):647654.

Tizard, I.R. 2012. Pages 320-323 in Veterinary Immunology. Elsevier Health Sciences.

Vanimisetti, H.B., S.P. Greiner, A.M. Zajac and D.R. Notter. 2004. Performance of hair sheep composite breeds: Resistance of lambs to Haemonchus contortus. J. Anim. Sci. 82:595604.

Woolaston, R.R. and L.R. Piper. 1996. Selection of Merino sheep for resistance to Haemonchus contortus: genetic variation. Anim. Sci. 62:451-460.

Wynn, T.A. and L. Barron. 2010. Macrophages: Master regulators of inflammation and fibrosis. Semin Liver Dis. 30(3)245-257.

Zajac, A.M., S. Krakowka, R.P. Herd and K.E. McClure. 1990. Experimental Haemonchus contortus infection in three breeds of sheep. Vet. Parasitol. (36):221-235. 